\title{
JUSTICES BLACK AND DOUGLAS: THE JUDICIAL FUNCTION AND THE SCOPE OF CONSTITUTIONAL LIBERTIES
}

\author{
TINSLEY E. YARBROUGH*
}

The retirement and death of Justice Hugo L. Black in Septeinber of 1971 brought to an end a long and distinguished judicial career. Also concluded was Justice Black's more than thirty years' association on the United States Supreme Court with Justice William O. Douglas, an association which had extended over most of the modern Court's history. During their years together on the nation's highest tribunal, the two jurists were allied in their voting on a variety of civil liberties issues. ${ }^{1}$ Indeed, so often did they concur on questions confronting the Court that Justice Douglas was moved to remark, in a 1956 law review tribute to Justice Black:

[W] hen one has been in such frequent agreement with a Brother as I have with Justice Black, it is impossible to write about him without seeming to write about one's self, or being so neutral as to appear to condemn by faint praise, or being so vague as to be stilted, or seeming to take advantage of the Brother's anniversary to perpetuate one's own favorite dissents. ${ }^{2}$

And almost ten years later, the situation was sufficiently unchanged that Justice Black could quote this observation in a lead article for a symposiun on Justice Douglas, commemorating his colleague's completion of twenty-five years' service on the Court. ${ }^{3}$

During the 1970 term, their last together on the Court, Justices Black and Douglas continued to vote alike in a wide assortment of civil liberties cases involving many of the same types of constitutional issues on which they had been traditionally allied. ${ }^{4}$ Even

* Associate Professor of Political Science, East Carolina University. B.A. 1963, M.A. 1965, Ph.D. 1967, University of Alabama.

1. The suniniary of civil liberties sub-group formations on the Court for the 1946-1969 terms indicates, for example, that Justices Black and Douglas were statistically grouped for every tern during the period except the $1969 \mathrm{term}$. S. Goldman \& T. Jahnige, The Federal Courts as a Political System 158-59 (1971).

2. Douglas, Mr. Justice Black: A Foreword, 65 YALE L.J. 449 (1956).

3. Black, William Orville Douglas, 73 YaLE L.J. 915 (1964).

4. See, e.g., New York Times Co. v. United States, 403 U.S. 713 (1971); Tilton v. Richardson, 403 U.S. 672 (1971); Lenıon v. Kurtzman, 403 U.S. 602 (1971); United States v. Thirty-Seven Photographs, 402 U.S. 363 (1971); Swann 
the most casual student of Supreme Court decision-making is aware, however, that increasingly in the years immediately preceding Justice Black's death, the two were found on opposite sides in heated debates over the nature and scope of important constitutional guarantees.

One possible explanation for the growing schisin between Justices Black and Douglas in their last years of association on the Court is that as Justice Black grew older he became progressively more "conservative." Glendon Schubert has been a principal exponent of this theory. Professor Schubert has contended that starting with his dissents in the 1964 sit-in cases, Justice Black began "to backslide, from what had been largely his public posture of staunch and outspoken and indeed activist support of both civil liberties and economic liberalisin . . . ".6 Thus, by the spring of 1969, Justice Black's opinions remaimed "liberal" only with regard to issues about orthodox aspects of political freedom, such as freedom of speech, and to the occasional cases on religious freedom or voting equality.? Either "biological aging" or "cnltural dissonance reflecting an unbridgeable void between the conceptual world of the elderly judge and that of the political actors who have generated the issues before him for decision"8 had made Justice Black, in Professor Schubert's judginent, a spokesman for "orthodox conservative dogina," a dogina incompatible with the Suprene Court's role in facilitating and controlling social change. ${ }^{10}$ Thus, while Justice Douglas continued to speak of "policy goals appropriate to American life in the twenty-first century," Justice Black was preoccupied, during his last years on the bench, "with restricting the Court to the support of those human rights that were deemed important in the eighteenth century." 11

In view of the substantial evidence indicating doubt that Justice Black should ever have been characterized as a "doctrinaire liberal,"12 and his repeated insistence that he had remaimed as

v. Charlotte-Mecklenburg Bd. of Educ., 402 U.S. 1 (1971); Law Students Civil Rights Research Council, Inc. v. Wadmond, 401 U.S. 154 (1971); In re Stolar, 401 U.S. 23 (1971); Baird v. State Bar, 401 U.S. 1 (1971).

5. E.g., Hamm v. City of Rock Hill, 379 U.S. 306, 318 (1964); Bell v. Maryland, 378 U.S. 226, 318 (1964).

6. G. SChubert, The Constitutional Polity 118 (1970).

7. Id. at 120 .

8. Id. at 127 .

9. Id. at 124 .

10. Id. at 127 .

11. Id. at 124 .

12. See S. Ulmer, The Longitudinal Behavior of Hugo Lafayette Black: Parabolic Support for Civil Liberties, 1937-1967 (unpnblished paper, presented at Sixty- 
consistent as humanly possible in his approach to constitutional and other legal issues, ${ }^{13}$ it would appear that his growing isolation from Justice Douglas and other "liberals" on the Court is attributable to some other factor than the aging process. This article focuses on contrasts in the positions of Justices Black and Douglas with respect to civil liberties issues of conteinporary significance. The underlying thesis of the paper is that their opposing views on such questions-increasingly conspicuous during the last decade of the Warren Court era and the first terms of the Burger Court-reflected deep-seated, long-enduring, and fundamentally different philosophies regarding the nature of law and the judicial function, ${ }^{14}$ rather than an aging justice's belated rejection of liberal tenets.

\section{The Judicial Function}

In seeking to explain conflicts among judges on collegial tribunals, students of public law frequently focus on judicial role concepts. ${ }^{15}$ As Walter F. Murphy and Joseph Tanenhaus have observed, the concept of role

is a pleasing notion in that it immediately explains in an intuitive manner inuch of the conflict that has occurred among judges. Oliver Wendell Holmes' dissent against the Social Darwinisn of. his colleagues was not basically grounded on substantive policy differences - for in his own way and for his own reasons Holmes was a believer in the gospel of laissez faire. Rather the nub of the dispute lay in competing sets of notions about what judges, as judges, should and should not do....

sixth Annual Meeting, American Political Science Association, Los Angeles, California, 1970).

13. H. Black, A Constitutional Farth 10-11 (1968); Interview with Hugo L. Black, in Washington, D.C., July 6, 1971.

14. This proposition, of course, is not new. In a highly perceptive article dealing with Justice Douglas' role in the development of the "new" equal protection, Kenneth L. Karst asserts: "In their opposing views about the content of the equal protection clause, Justices Black and Douglas reflect fundamentally different approaches to the judicial function in constitutional interpretation." Karst, Invidious Discrimination: Justice Douglas and the Return of the "Natural-LawDue-Process Formula," 16 U.C.L.A. L. REv. 716, 717 (1969). Note also Harry Kalven's observation in an article on Justice Black's approacli to contemporary free speech problems:

A profitable study might ... be made of Justice Black and Justice Douglas who have spent twenty-six years on the Court together; while they very often vote together, they sliow an interesting tendency to write their own opinions. Kalven, Upon Rereading Mr. Justice Black on the First Amendment, 14 U.C.L.A. L. REv. 428, 435 n.29 (1967).

15. Here, the term "role" is used in a normative sense to refer to "a set of notions about the proper way for a person who holds a particular position or status to behave." W. Murphy \& J. Tanenhaus, The Study of Public Law 140 (1971). 
In the 1930's Harlan Fiske Stone's long debate with George Sutherland and the other Four Horsemen who fought the New Deal was over the same fundamental issue of role, not substantive policy. ${ }^{10}$

Contemporary judicial role analyses, ${ }^{17}$ whether employing the term "role" in a general or more systematic manner, have normally categorized judges as either "judicial activists" or proponents of "judicial self-restraint." While useful as a tool for distinguishing the views of judges regarding the position of courts relative to other actors in a political system, the "activist"/"self-restrainer" dichotomy seems rather too narrow a frannework for a general analysis of the judicial philosophy of a judge. Another, somewhat broader approach to an understanding of judicial role concepts is to examine similarities between the judicial philosophy of individual judges and the role models inherent in the three major American schools of jurisprudence-the natural law school, the positive law school, and the sociological law school. ${ }^{18}$ Obviously, a role concept is not the only force explaining judicial decision-making; at least for certain judges, however, the influence of one or more of these jurisprudential theories may furnish an important key to an understanding of judicial nnotivation.

\section{The Sociological-cum-Natural-Law Approach of Justice Douglas}

Justice Douglas' opimions, often little more than a series of conclusory statements, suggest that he is largely unconcerned with articulating a coherent, imternally consistent constitutional and judicial philosophy; ${ }^{19}$ and an exainination of his numerous off-the-bench writings leads one to the saine conclusion. The explanation for this tendency may or may not lie in the statement by Fred Rodell that, "despite his vast intellectual attainments, Douglas is not primarily a cerebral man. Wisdom, to him, is worthless in the abstract . . . . [H]e is a man of action and decision rather than con-

16. Id. at $140-41$.

17. See id. at 140-44 (brief survey of behavioral literature dealing with judicial role concepts).

18. Selected writings illustrative of these three approaclies to law and the judicial function are collected in The Nature of Law: ReAdings in Legal PhilosoPHY (M. Golding ed. 1966). See also E. BODENHEIMER, JURISPRUDENCE (1962).

19. For a recent expression of the scholar's concern for Justice Douglas' opinion-writing habits, see Van Alstyne, The Constitutional Rights of Public Employees: A Comment on the Inappropriate Uses of an Old Analogy, 16 U.C.L.A. L. REv. 751, 772 (1969). Professor Van Alstyne characterizes Douglas' opinions as, among other things, "brusque and restless," "[causing] fits to readers," "fair game to critics," and "untidy and almost careless in their flow." 
templation."20 But whatever the cause, the result is to make analysis of Douglas' position on legal issues and his concept of the judge's role exceedingly difficult. Nevertheless, it is possible to discern in Douglas' work strams of both the sociological and natural law approaches to the judicial function.

During their early years on the Court, Douglas, Black, and the other Roosevelt appointees were primarily concerned with dismantlimg the constitutional obstacles to economic and social legislation erected by the pre- 1937 Court. A principal theme of the Court's opinions in economic cases decided during Douglas' first years on the bench was the contention, central to the sociological approach to the judicial function, that courts should allow the political branches of government ample freedom to deal effectively with critical social problens. Justice Douglas, of course, was a spokesman for this view. ${ }^{21}$ Indeed, as late as 1961 , lie wrote that the "error of the old Court [lay in stopping] experimentation and the testing of new decrees and controls, [thereby depriving] society of a needed versatility."22

A lecture on stare decisis, delivered by Douglas before the Association of the Bar of the City of New York, is, however, perhaps the best evidence of his acceptance of the sociological approacl. In the lecture, part of a series lionoring the memory of Benjamin N. Cardozo who was a leading figure in the sociological scliool, Douglas agreed that the principle of stare decisis sliould not be considered "so fragile a thing as to bow before every wind."23 "The law

20. Rodell, Justice Douglas: An Anniversary Fragment for a Friend, 26 U. CHr.

L. REv, 2, 6 (1958). Justice Douglas himself has written:

I often think that a disproportionate part of the energies of our profession is devoted to the semantics of the law. The formulation of doctrine, the writing of briefs, the preparation of opinions are critically important. Reasoned opinions are essential for the integrity of the judicial process. Briefs that throw light into dark corners are essential. Criticism by the profession of the work of the courts and legislatures is vital to any healthy system. Yet it often seems that the discourse with which we tend to preoccupy ourselves is pretty much in the pattern of theological discourse. The priests of the profession argue and debate about nice points of law that may seein important to those who lead smug lives in ivory towers but quite unimportant in the life of the nation. Douglas, Vagrancy and Arrest on Suspicion, 70 Yale L.J. 1 (1960).

21. See, for example, his opinion of the Court in Olsen v. Nebraska ex rel. Western Reference \& Bond Ass'n, 313 U.S. 236 (1941). In an article examining Justice Douglas' approach to economic issues, the author concluded: "Douglas . . . has made it plain that he is consciously concerned with the development of judicial doctrines that lead to what he believes to be socially desirable results." Epstein, Economic Predilections of Justice Douglas, 1949 Wis. L. REv. 531, 562.

22. Poe v. Ullman, 367 U.S. 497, 517-18 (1961) (Douglas, J., dissenting).

23. Douglas, Stare Decisis, 4 RECORD OF N.Y.C.B.A. 152 (1949). 
is not properly susceptible to whim or caprice. It must have the sturdy qualities required of every framework that is designed for substantial structures. Moreover, it must have uniformity when applied to the daily affairs of men."24 Nevertheless, in his view it seemed "easy ... to overemphasize stare decisis as a primciple in the lives of men." ${ }^{25}$ The Constitution, he maintained, should not be allowed to "freeze in the pattern which one generation gave it, [or] become a code which carries the overtones of one period that may be hostile to another, [for it] was designed for the vicissitudes of time."26 Where constitutional law is concerned, the principle of "stare decisis must give way before the dynamic.component of history."

Therefore, according to Justice Douglas, the Supreme Court must be mindful, in construing the Constitution, of the social implications of its pronouncements. He further observed:

Precedents are made or unmade not on logic and history alone. The choices left by the generality of a constitution relate to policy. ... The problem of the judge is to keep personal predilections from dictating the choice and to be as faithful as possible to the architectural scheme. We can get from those who preceded a sense of the continuity of a society. We can draw from their learning a feel for the durability of a doctrine and a sense of the origins of principles. But we have experience that they never knew. Our vision may be shorter or longer. But it is ours. It is better that we make our own history than be governed by the dead. We too must be dynamic components of history if our institutions are to be vital, directive forces in the life of our age. ${ }^{28}$

In Douglas' view, moreover, there should be no attempt to conceal judicial adaptations of law to changing social needs behind what Judge Jerome Frank termed "a verbal disguise of fixity and universality." ${ }^{29}$ Rather, judges should candidly acknowledge their role in the creation of law.

[T] he more blunt, open, and direct course is truer to democratic traditions. It reflects the candor of Cardozo . . . . A judiciary that discloses what it is doing and why it does it will breed understanding. And confidence based on understanding is more enduring than confidence based on awe. ${ }^{30}$

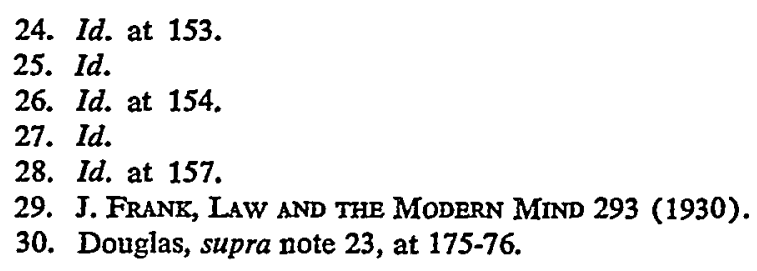


Thus, if one assumes that Douglas continues to adhere to the views set forth in his lecture on stare decisis, there are clearly aspects of the sociological approach in his philosophy of the judicial function. Like leading figures in the sociological school, he believes that the Constitution is "designed for the vicissitudes of time" and should not be allowed "to freeze in the pattern which one generation gave it." Similarly, he agrees with those in the sociological tradition that judges are "dynamic components of history" and that the "generality of a constitution" allows them to make policy choices in construmg the Constitution-choices dictated by societal needs. Finally, he behieves, as did Cardozo, ${ }^{31}$ that judges should candidly acknowledge their role in policy formation.

As noted previously, there are also elements in Justice Douglas' thinking of the natural law conception of the judge as a seeker of "justice." It is debatable whether Douglas is as doctrinaire a civil libertarian as certain others with whoin he has served on the Court, including Justices Murphy, Rutledge, Goldberg, Fortas, Brennan and Marshall. Nevertheless, his devotion to the protection of personal hiberties against arbitrary governmental action is well documented, and he has been a constant seeker, it seems, of new ways in which to enhance the scope of individual rights under the Constitution. ${ }^{32}$ Moreover, it is his view that the rights which the Constitution guarantees are "natural rights," having "a broad base in norality and religion," and consisting not inerely of the safeguards "written explicitly into the Constitution" but also of rights within the "penumbra" of the Bill of Rights and "implied from the very nature of nnan as a child of God."33 This sort of thinking parallels rather closely the view of the natural law theorists that judges should declare void governmental practices which infringe on "natural rights," even where the practices in question violate no specific provision of even the nost basic of human laws. Furthermore, at least one recent study has focused on the strong similarities between Justice Douglas' interpretation of the equal protection guarantee of the fourteenth amendment and the pre-1937 Court's "natural law" interpretation of the Constitution's due process require-

31. See, e.g., B. Cardozo, The Nature of the Judicial Process 10-11 (1928). This study includes Justice Cardozo's famous statement: "I take judge-made law as one of the existing realities of life." Id. at 10.

32. See, for example, the use by Douglas of the "penumbra" concept, most clearly articulated by him in Griswold v. Connecticut, 381 U.S. 479 (1965), and in his dissent in Palmer v. Thompson, 403 U.S. 217, 231 (1971). See notes 133-46 infra and accounpanying text.

33. W. Dovglas, The Right of the People 89 (1958). 
ments. ${ }^{34}$ And, shortly before his death, Justice Black, too, said that Douglas" approach to certain civil liberties issues "finally merge[s]" with the "natural law" philosophy of Justice Stephen Field and other members of the Old Court. ${ }^{35}$

In view of the fact that the sociological approach developed in part as a reaction to the uses of the "natural law" theories by the Old Court, it might appear strange to contend that Douglas' conception of law and the judicial function contains elennents of both schools of jurisprudence. Actually, however, the two theories are compatible in at least one important respect: Whether a judge conceives of himself as a "social engineer" or as a defender of concepts of "natural justice," he is rejecting the notion that judicial decision-making is an essentially mechanical function in which individual value concepts and policy preferences should exert little or no influence.

\section{The Legal Positivism of Justice Black}

Justice Black's judicial approach, as depicted by certain students of his career, bears strong similarities to both the natural law ${ }^{30}$ and sociological ${ }^{37}$ schools of jurisprudence. Black, however, vigorously rejected both the natural law and sociological concepts of the judge's role. His opposition to the pre-1937 Court's use of due process as a "natural law" tool for ruling upon the "reasonableness" of economic legislation is well known, ${ }^{38}$ as is his position that the "natural-law-due-process" formula is "no less dangerous when used to enforce [the] Court's views about personal rights than those about economic rights." 38 Even before his appointment to the Court, in fact, Black spoke out frequently in the Umited States Senate against the uses by the Court's conservatives of the Constitution's "elastic" due process provisions in economic cases. ${ }^{40}$ Moreover,

34. Karst, supra note 14.

35. Interview with Hugo L. Black, supra note 13.

36. See, e.g., W. Mendelson, Justices Black and Frankfurter: Conflict in the Court 121 (1961); C. Williams, Hugo L. Black: A Study in the Judicial Process 189 (1950).

37. See, for example, Reich, Mr. Justice Black and the Living Constitution, 76 Harv. L. Rev. 673, 747 (1963). In the article, Professor Reich, a former law clerk for Justice Black, observes, for example, that the Justice's philosophy of the judicial function permitted "doctrine to keep pace with the times." Id. See also C. WILIIAMS, supra note 36, at 189.

38. See, e.g., his majority opinion in Ferguson v. Skrupa, 372 U.S. 726, 728-29 (1963).

39. Griswold v. Connecticut, 381 U.S. 479, 522 (1965) (Black, J., dissenting).

40. On this point, see Haigh, Defining Due Process of Law: The Case of Mr. Justice Hugo L. Black, 17 S. DAK. L. REv. 1, 25-26 (1971). 
very early in their respective careers on the Court, Justice Frankfurter's correspondence with Black focused at times on Black's opposition to judges who attempt to read into the Constitution and the laws of the nation their notions of what is "right." In one letter, for example, Justice Frankfurter wrote: "I am aware that men who have power can exercise it-and too often do-to enforce their own will, to inake their will, or if you like their notions of policy, the measure of what is right." 41 And later in the letter, apparently in retort to sentiments expressed earlier by Black, he further observed: "I appreciate the frailties of men, but the War is for me meaningless and Hitler becomes the true prophet if there is no such thing as Law different from or beyond the individuals who gave it expression . . . ."42

Black's opposition to the view that judges are clothed with authority to adapt law to changing times was perhaps most clearly expressed in his dissenting opinion in Griswold $v$. Connecticut, ${ }^{43}$ where he wrote:

I realize that many good and able men have eloquently spoken and written, sometimes in rhapsodical strains, about the duty of this Court to keep the Constitution in tune with the times. The idea is that the Constitution must be changed froin time to time and that this Court is charged with a duty to make those changes. For myself, I must with all deference reject that philosophy. The Constitution makers knew the need for change and provided for it. Amendments suggested by the people's elected representatives can be submitted to the people or their selected agents for ratification. That method of change was good for our Fathers, and being somewhat old-fashioned I must add it is good enough for ine. ${ }^{44}$

41. Letter from Felix Frankfurter to Hugo L. Black, Nov. 13, 1943, on file in the Felix Frankfurter Papers, Library of Congress.

42. Id. See also Letter from Felix Frankfurter to Hugo L. Black, Dec. 15, 1939, on file in the Felix Frankfurter Papers, Library of Congress. Justice Black's opinions, of course, frequently criticized what he saw as natural law elements in Justice Frankfurter's constitutional philosophy. About a year after Frankfurter's November 13, 1943, letter to Black, for example, a Black dissent accused Frankfurter of "interpreting legislative enactments on the basis of ... preconceived views on 'inorals' and 'ethics." Mercoid Corp. v. Mid-Continent Inv. Co., 320 U.S. 661, 673 (1944) (Black, J., dissenting). See also, Rochin v. California, 342 U.S. 165, 174 (1952) (Black, J., concurring); Adamson v. California, 332 U.S. 46, 68 (1947) (Black, J., dissenting).

43. 381 U.S. 479 (1965).

44. Id. at 522. During his last tern on the Court, Justice Black reiterated this position in concluding that the "crnel and unusual punishments" provision of the eighth amendment could not be construed as prohibiting capital punishment. McGautha v. California, 402 U.S. 183, 225 (1971) (Black, J., concurring). He 
In another article, ${ }^{45}$ I characterized Justice Black's philosophy of law and the judicial function as being closely aligned with that advanced by adherents of legal positivism. In doing so, I took a cue from Black's leading jurisprudential antagonist during their years together on the Court, Justice Frankfurter. Frankfurter early compared Black's thinking with the theories of the utilitarian Jeremy Benthain, whose views in the realm of law resembled rather closely the ideas of early legal positivists such as John Austin. On December 15, 1939, Frankfurter wrote his colleague a lengthy letter ${ }^{48}$ regarding the "jurisprudential problem" underlying their different approaches in reaching the same legal result in a pending case. In the letter, he recalled that "[s]ome time ago at the end of a, to me, very stimulating talk between us, I told you that you were a Benthamite." After assuring Black that he considered the term "fundamentally" one "of praise," since, in his judgment, Bentham was "the most fruitful law reformer of the Nimeteenth Century," Frankfurter proceeded in the letter to outline what he believed to be extremes in Bentham's-and thus, by implication, Black's-thinking. He wrote that,

as is so often true of a reformer who seeks to be rid of the accumulated abuses of the past, Bentham at times threw out the baby with the bath. In his rigorous and candid desire to rid the law of many far-reaching abuses introduced by judges, he was not unnaturally propelled to the opposite extreme of wishing all law to be formulated by legislation, deeming most that judges do a usurpation by incompetent men as to matters concerning which he believed them guilty of "judicial legislation."

Although agreeing that "judicial legislation in its invidious sense" should be opposed, Frankfurter condemned as "equally mischievous ... the notion that judges merely amounce the law which they find and do not themselves inevitably have a share in the law-

wrote, that in his view,

these words cannot be read to outlaw capital punishment because that penalty was in common use and authorized by law here and in the countries from which our ancestors came at the time the Amendment was adopted. It is inconceivable to me that the Framers intended to end capital punishment by the Amendment. Although some people have urged that this Court should amend the Constitution by interpretation to keep it abreast of modern ideas, I have never believed that lifetime judges in our system have any such legislative power. Id. at 226 .

Note also Justice Black's observation, during a 1968 interview: "I don't claim any right to keep the Constitution up to date. I've sustained laws as constitutional that I was bitterly against--didn't agree with them." Text of Historic TV Interview of Justice Black, 27 CoNG. Q. WeEkLY ReP., Jan. 3, 1969, at 6.

45. Yarbrough, Mr. Justice Black and Legal Positivism, 57 VA. L. REv. 375 (1971).

46. Letter from Felix Frankfurter to Hugo L. Black, supra note 42. 
making." Such a notion, he charged, was "founded on an untruth and an impossible aim," for, among other things, judges obviously "cannot escape the responsibility of filling in gaps which the finitude of even the most imaginative legislation renders inevitable."47

Frankfurter concluded the letter with a criticism frequently leveled at legal positivist thinking:

I think one of the evil features, a very evil one, about all this assumption that judges only find the law and don't make it, often becomes the evil of a lack of candor. By covering up the lawmaking function of judges, we miseducate the people and fail to bring out into the open the real responsibility of judges for what they do....

In my own coinparison of Justice Black's philosophy with legal positivism, I concluded that at least four major legal positivist tenets formed the core of Black's judicial approach. ${ }^{48}$ These inay be summarized briefly. First, central to Black's philosophy was the position that lawmaking is a legislative, not a judicial, function, and that lawmaking through normal legislative channels is preferable to legislation by other governmental agencies, mcluding the courts. Second, he believed that, in construing the meaning of a law, judges should seek to determine the intent of its framers through an examination of the "literal ineaning" of the words used m the law or other indicia of intent. Like the legal positivists, he realized that situations might arise in which two or nore interpretations appeared equally possible, and in such instances, he agreed, a judge is obviously free to apply that interpretation believed to have the greatest intrinsic merit. In his view, however, such "penuunbral" situations rarely arise; and when the intent of the framers seems clear, then that interpretation must be accepted, even though another might yield what the judge considers a more "just" or "socially desirable" result. Third, Black accepted the legal positivist contention that, in a sense, law and morals are separate entities. He was well aware, of course, that moral concepts have had a tremendous influence on the development of legal systems, but he also agreed with the proposition of the modern legal positivist H.L.A. Hart that

47. More recently, Paul Freund has written that "[t]here is more than a touch of Jeremy Bentham in Justice Black." Freund, Mr. Justice Black and the Judicial Function, 14 U.C.L.A. L. REv. 467, 473 (1967). Justice Black, it should also be noted, considered himself "a great admirer of Jeremy Bentham." Interview with Hugo L. Black in Washington, D.C., Aug. 31, 1970.

48. Justice Black strongly concurred with each of these four legal positivist principles and with the characterization of his philosophy presented in the study. Interview with Hugo L. Black, supra note 47; Letter from Hugo L. Black to Tinsley E. Yarbrough, Oct. 13, 1970. 
in the absence of an expressed constitutional or legal provision, it could not follow from the mere fact that a rule violated standards of morality that it was not a rule of law; and, conversely, it could not follow from the mere fact that a rule was morally desirable that it was a rule of law. 49

Finally, inotivated at least in part no doubt by a desire to reduce the scope of judicial discretion and a belief that the law should be comprehensible to the coinmon man as well as to the legal scholar, Black stressed, throughout his career, the need for clarity, precision, and consistency in the law.

If this description of Justice Black's approach be correct, his philosophy of law and the judicial function was, in essence, one which rejected the view that judges should-or, inevitably, mustallow their conceptions of what is "right" or their social and economic predilections to shape their interpretations of constitutional provisions. By contrast, Justice Douglas' philosophy, as depicted earlier in this article, is one which accepts the idea that the Constitution has a "dynamic" quality, holds that constitutional interpretation should be adapted to changing social conditions, and regards the Constitution as, among other things, an imstrument for ever broadening the scope of man's "natural rights" accorded legal recognition. As hopefully will be shown in the remainder of this article, these conflicting judicial philosophies are clearly reflected inand may account for-their opposing positions on a number of important civil liberties issues, imcluding debates over the nature of due process, the "penumbral" theory, the scope of the fourth amendment, and the nature of the equal protection guarantee.

\section{The Nature of Due Process}

Justice Black's opinion in 1968 in Duncan v. Louisiana $a^{50}$ was one of the last cases in which he discussed extensively his views regarding the nature of the constitutional guarantee of due process. ${ }^{51}$ The Duncan case is one of the inost recent in the series of Supreme Court decisions incorporating into the meaning of the fourteenth aunendment due process clause those rights in the Bill of Rights which the Court deems "fundaunental."52 Speaking for the

49. Hart, Positivism and the Separation of Law and Morals, 71 HARv. L. REv. 593,599 (1958).

50. 391 U.S. 145 (1968).

51. See also In re Winship, 397 U.S. 358, 377 (1970) (Black, J., dissenting). Perhaps Black's most fully developed statement of his philosophy of due process is to be found in H. BLACK, supra note 13, at 23-42.

52. The most recent decision is Benton v. Maryland, 397 U.S. 784 (1969), incorporating the fifth amendment's "double jeopardy" provisions into the mean- 
majority in the case, Justice White held that the right to trial by jury in criminal cases, required in federal trials under the sixth amendment, was "fundamental to the American scheme of justice" and thus part of the due process demanded of states under the fourteenth amendment. ${ }^{53}$

In a concurring opinion, Justice Black professed satisfaction that the "selective imcorporation" approach employed by a majority on the Court in defining due process under the fourteenth amendment had worked to make most of the Bill of Rights applicable to the states, and noted that the selective process,

if used properly, does limit the Supreme Court in the Fourteenth

Amendment field to specific Bill of Rights protections only and keeps

judges from roaming at will in their own notions of what policies

outside the Bill of Rights are desirable and what are not. ${ }^{54}$

Black also reiterated his own well-known theory of "total incorporation"- the view, first fully developed by him in his dissenting opinion in Adamson v. California, ${ }^{55}$ that the provisions of the first section of the fourteenth amendment, taken as a whole, were intended by the amendment's framers to make the Bill of Riglits fully applicable to the states. Much of his Duncan opinion, however, was devoted to a discussion of his interpretation of due process as an independent constitutional requirement and to criticism of the interpretation of due process advanced by Justice Harlan in a dissenting opinion.

Justice Harlan's due process philosophy ${ }^{56}$ was closely tied to the substantive due process approach utilized by the Court in late nineteenth and early twentieth century economic cases, ${ }^{57}$ the concepts of procedural due process espoused by the Court in early criminal procedure cases rejecting the incorporation theory, ${ }^{58}$ and the

ing of the fourteenth amendment's due process clause. For a summary of the history of the "incorporation" process and the continuing debate on and off the Court over the relationship between the Bill of Rights and the fourteenth amendment, see H. ABRAHAM, FREEDOM AND THE COURT 26-79 (1967).

53. 391 U.S. at 149.

54. Id. at 171 .

55. 332 U.S. 46,68 (1947).

56. For other statements of Justice Harlan's due process views, see Griswold v. Connecticut, 381 U.S. 479, 499 (1965) (Harlan, J., concurring); Malloy v. Hogan, 378 U.S. 1, 14 (1964) (Harlan, J., dissenting); Mapp v. Ohio, 367 U.S. 643, 672 (1961) (Harlan, J., dissenting); Poe v. Ullman, 367 U.S. 497, 522 (1961) (Harlan, J., dissenting).

57. See, e.g., Adkins v. Children's Hospital, 261 U.S. 525 (1923); Coppage v. Kansas, 236 U.S. 1 (1915); Lochner v. New York, 198 U.S. 45 (1905); Allgeyer v. Louisiana, 165 U.S. 578 (1897) (a case decided on narrow grounds but containing much substantive due process dicta).

58. See, e.g., Twining v. New Jersey, 211 U.S. 78 (1908). 
due process notions of his jurisprudential mentor, Justice Frankfurter. ${ }^{59}$ In his Duncan dissent, Harlan asserted that the Court's selective incorporation approach represented "an uneasy and illogical compromise among the views of various Justices on how the Due Process Clause should be interpreted," and maintained that the approach and the Court's "reading of history are altogether topsyturvy." "at least have the virtue, lacking in the Court's selective incorporation approach, of internal consistency," but it, too, he argued, was supported neither by "history, nor sense." In In his view there was, in fact, only one acceptable method of defining and giving content to the words of the Constitution's due process provisions:

That is to start with the words "liberty" and "due process of law" and attempt to define them in a way that accords with American traditions and our system of government. This approach, involving a much more discriminating process of adjudication than does "incorporation," is, albeit difficult, the one that was followed throughout the 19th and most of the present century. It entails a "gradual process of judicial inclusion and exclusion," seeking, with due recogmition of constitutional tolerance for state experimentation and disparity, to ascertain those "immutable principles . . . of free government which no member of the Umion may disregard." Due process was not restricted to rules fixed in the past, for that "would be to deny every quality of the law but its age, and to render it incapable of progress or improvement." Nor did it impose nationwide uniformity in details . . . .

Through this gradual process, this Court sought to define "liberty" by isolating freedoms that Americans of the past and of the present considered more important than any suggested countervail-

59. For an expression of Justice Frankfurter's views on the nature of due process, see, e.g., Adamson v. California, 332 U.S. 46, 59 (1947) (Frankfurter, J., concurring).

60. 391 U.S. at 172, 173.

61. Id. at 175-76. In a footnote, Harlan also raised the contention, perhaps first leveled against Black's total incorporation theory by Justice Frankfurter in Adamson v. California, 332 U.S. 46, 63 (1947) (Frankfurter, J., concurring), that "the great words of the four clauses of the first section of the Fourteenth Amendment would have been an exceedingly peculiar way to say that" the Bill of Rights was thereafter to be applicable to the states. 391 U.S. at 175 n.9. In his concurring opinion in Duncan, Black replied that the words of the fourteenth amendment's privileges and immunities section seemed to him "an eminently reasonable way of expressing the idea that henceforth the Bill of Rights shall apply to the States," $i d$. at 166 , adding:

My view has been and is that the Fourteenth Amendment, as a whole, makes the Bill of Rights applicable to the States. This would certainly include the language of the Privileges and Immunities Clause, as well as the Due Process Clause. Id. at 166 n.1. 
ing public objective. The Court also, by interpretation of the phrase "due process of law," enforced the Constitution's guarantee that no State may imprison an individual except by fair and impartial procedures. ${ }^{62}$

For Black, the sort of approach to due process endorsed in Harlan's dissent was one which treated

the Due Process Clause . . . as prescribing no specific and clearly ascertainable constitutional command that judges inust obey in interpreting the Constitution, but rather as leaving judges free to decide at any particular time whether a particular rule or judicial formulation embodies an "immutable principl[e] of free government" or is "implicit in the concept of ordered liberty," or whether certain conduct "shocks the judge's conscience" or runs counter to some other similar, undefined and undefinable standard. ${ }^{63}$

Viewed in this way, Black charged, the meaning of due process "is found to shift from time to time in accordance with judges' predilections and understanding of what is best for the country," and varies also according to "the particular judge's idea of ethics and morals." It was imconceivable to him "that such unconfimed power is given to judges in our Constitution that is a written one in order to limit governmental power."

Answering Harlan's contention that the incorporation theory unduly restricts state power and thus interferes with the American federal concept, Black wrote that he had "never believed that under the guise of federalism the States should be able to experiment with the protections afforded our citizens through the Bill of Rights."60 He further observed:

It seems to ine totally inconsistent to advocate, on the one hand, the power of this Court to strike down any state law or practice which it finds "unreasonable" or "unfair" and, on the other hand, urge that the States be given inaximum power to develop their own laws and procedures . . . No one is inore concerned than I that the States be

62. Id. at $176-77$.

63. Id. at 168. In a footnote to the Griswold dissenting opinion, Justice Black listed a large number of the "undefined and undefinable" standards "invoked by judges who would strike down under the Fourteenth Amendment laws which offend their notions of natural justice ..." 381 U.S. at 511 n.4. He concluded the footnote with the observation:

Perhaps the clearest, frankest and briefest explanation of how this due process approach works is the statement in another case handed down today that this Court is to invoke the Due Process Clause to strike down state procedures or laws which it can "not tolerate." $I d$, at 512 n.4.

64. 391 U.S. at 168-69.

65. Id. at 168 .

66. Id. at 170 . 
allowed to use the full scope of their powers as their citizens see fit. And that is why I have continually fought against the expansion of this Court's authority over the States through the use of a broad, general interpretation of due process that permits judges to strike down state laws they do not like. ${ }^{67}$

In Justice Black's view, the due process guarantee in the Constitution had the same meaning essentially as the "law of the land" provision of the English Magna Carta, from which the due process concept originally developed. Chapter 39 of the Magna Carta provided: 'No free man shall be taken, outlawed, banished, or in any way destroyed, nor will We proceed against or prosecute him, except by the lawful judgment of his peers and by the law of the land." ${ }^{\circ 8}$ This provision, said Black, was designed to assure "that the government would take neither life, liberty, nor property without a trial in accord with the law of the land that already existed at the time the alleged offense was committed."69 The due process guarantee in the United States Constitution, he maintained, had the saine purpose.

[T]he Due Process Clause gives all Americans, whoever they are and wherever they happen to be, the right to be tried by independent and unprejudiced courts using established procedures and applying valid pre-existing laws. There is not one word of legal history that justifies unaking the term "due process of law" mean a guarantee of a trial free from laws and conduct which the courts deem at the time to be "arbitrary," "unreasonable," "unfair," or "contrary to civilized standards." The due process of law standard for a trial is one in accordance with the Bill of Rights and laws passed pursuant to constitutional power, guaranteeing to all alike a trial under the general law of the land. ${ }^{70}$

Justice Black apparently developed his views regarding due process and the relationship between the Bill of Rights and the fourteenth aunendment during his first decade on the Supreme Court. Shortly after his appointment to the Court, Palko v. Connecticut ${ }^{71}$ was decided. In Palko, Justice Cardozo's opinion for the majority of the Court rejected the total incorporation argument and contained elements of both the selective incorporation doctrine and the due process approach later advanced by Justices Frankfurter and Harlan. Nevertheless, Black voted with the majority, ${ }^{72}$ for at this point,

67. Id. at 170-71.

68. Magna Carta, 25 Edw. 1, c.39 (1297).

69. 391 U.S. at 169.

70. Id. at $169-70$.

71. 302 U.S. 319 (1937).

72. The lone dissenter in the case, Justice Butler, dissented without opinion. 
he later said, he had not fully developed his views about the meaning of the fourteenth amendment. ${ }^{73}$ His majority opinion in the 1940 coerced-confession case, Chambers v. Florida, ${ }^{74}$ included language characteristic of the Frankfurter-Harlan interpretation of due process. He also spoke, however, of the "current of opinion" that "the Fourteenth Amendment was intended to make secure against state invasion all the rights, privileges and immunities protected froin federal violation by the Bill of Rights . . .."75 And in describing the content of due process he mentioned the "law of the land" concept, ${ }^{76}$ the Bill of Rights, and the safeguards provided in the original Constitution. ${ }^{77}$ Moreover, two years later, in Betts $v$. $B r a d y,{ }^{78}$ he dissented from the majority decision that counsel was required only in those state criminal cases where "special circumstances" dictated appointment of counsel in order to assure a "fair trial." In his dissenting opinion, he stated that, in his view, "the Fourteenth Amendment made the Sixth applicable to the states," and termed the "prevailing view of due process, as reflected in the opinion just announced," one "which gives this Court such vast supervisory powers that I am not prepared to accept it without grave doubts. ...."79

Also of interest as evidence of Black's continuing concern, during the early stages of his Supreme Court career, about the nature of due process and the fourteenth amendment's relation to the Bill of Rights is Justice Frankfurter's letter to Black of November 13, $1943,{ }^{80}$ referred to previously in this article. ${ }^{81}$ After discussing at length the problem of tying judges "down by specifia provisions that would bind them," Frankfurter noted in the letter, with perhaps a hint of sarcasm, that he would

be grateful to you if you will refer me to the materials which justify one in saying that the general language of the Fourteenth Amendment was in fact a compendious statement of some or all of the earlier first nine Amendments .... Is it conceivable that an amendment bringing about such a result would either have been submitted to the states, or, if submitted, would have been ratified by thein.

... Believe me that in writing this nothing is farther from my

73. Interview with Hugo L. Black, supra note 13.

74. 309 U.S. 227 (1940).

75. Id. at $23.5-36$ n.8.

76. Id. at 236 .

77. Id. at 237 n. 10 .

78. 316 U.S. 455 (1942).

79. Id. at $474-75$.

80. Letter from Felix Frankfurter to Hugo L. Black, supra note 41.

81. See notes $41-42$ supra and accompanying text. 
purpose than contention. I am merely trying to get light on a subject which has absorbed as much thought and energy of my mature life as anything that has concerned me. I ask you quite humbly to lead me to the inaterials that the Fourteenth Aunendment incorporates by reference the provisions-any or all-of the earlier nine Amendments. Needless to say there is no hurry about this. Whenever you feel inclined to help educate me, I shall be grateful.

Finally, of course, in 1947 in Adamson v. California, ${ }^{82}$ Black wrote a lengthy dissenting opinion-his most significant opinion, he was later to say, even after the conclusion of his last term on the Court ${ }^{83}$-in which he launched a vigorous atttack on "the natural-law-due-process formula" and developed fully for the first time his total incorporation doctrine, observing:

My study of the historical events that culminated in the Fourteenth Amendment, and the expressions of those who sponsored and favored, as well as those who opposed its submission and passage, persuades me that one of the chief objects that the provisions of the Amendment's first seetion, separately, and as a whole, were intended to accomplisl was to make the Bill of Rights apphicable to the states. ${ }^{84}$

Throughout his years on the Court, Justice Black remained largely faithful to his view that, aside from defining United States and state citizenship and guaranteeing equal protection, the first section of the fourteenth amendment simply applied the Bill of Rights to the states and, through its due process clause, guaranteed that no state could deny a person life, liberty, or property except by the "law of the land," a restraint imposed on the federal government under the fifth amendment. ${ }^{85}$ As noted earlier, he consistently rejected the substantive due process philosophy einployed by the pre-1937 Court in striking down as unconstitutional economic legislation deemed "unreasonable," "capricious," or "arbitrary,"80 even where such a decision would have resulted im aiding economic interests important to one with a populist political background, such

82. 332 U.S. 46 (1947).

83. Interview with Hugo L. Black, supra note 13.

84. 332 U.S. at 71-72.

85. In at least one respect, however, Justice Black deviated from this rather restricted view of the fourteenth amendment's scope. He joined in a concurring opinion filed by Justice Douglas in Edwards v. California, 314 U.S. 160, 177 (1941), in which Douglas argued that the privileges and immunities provision of the first section of the fourth amendment guaranteed a right to interstate travel. Shortly before his death, Justice Black reiterated his acceptance of this view, adding that his was not a "logically pure" constitutional and judicial philosophy but "only as [logically pure] as humanly possible." Interview with Hugo L. Black, supra note 13.

86. See, e.g., Ferguson v. Skrupa, 372 U.S. 726 (1963) (Black, J.). 
as Black himself. ${ }^{87}$ He was equally adamant in his opposition to the utilization of substantive due process notions to invalidate legislation infringing unduly on personal freedoms, despite the fact that such a law might be "every bit as offensive"88 to him as to those members of the Court willing to declare it void. ${ }^{80}$ Moreover, perhaps in contrast with the views of all the justices with whom he served on the Court, he rejected the idea that the due process provisions demanded adherence to standards of procedural "fairness" other than those grounded in the specific language of the Constitution. In the 1970 case of In re Winship ${ }^{90}$ for example, he dissented from the majority's decision that "proof beyond a reasonable doubt is among the "essentials of due process and fair treatment." "91 Finally, he refused to agree that the due process guarantee extends to civil proceedings since, "[i]n such cases the government is not usually involved as a party, and there is no deprivation of life, liberty, or property as punishment for crime." 92

Justice Black's reading of the history surrounding the framing of the fourteenth amendment and his conclusion that the amendment was intended to apply the Bill of Rights to the states have been subjected to frequent and intense criticism, ${ }^{93}$ as has his use of his-

87. See Lincoln Fed. Labor Union v. Northwestern Iron \& Metal Co., 335 U.S. 525 (1949) (Black, J.). ing).

88. Griswold v. Connecticnt, 381 U.S. 479, 507 (1965) (Black, J., dissent-

89. See, e.g., id.

90. 397 U.S. 358 (1970).

91. Id. at 359. In a recent article on Justice Black's interpretation of due process, Roger Haigh examined those cases in which Black wrote, or joined in, opinions articulating due process standards without reference to specific safeguards in the Bill of Rights. Haigh, supra note 40, at 20-24. (His findings are suinmarized in an appendix to the article. Id. at 40.) Professor Haigh concluded that a number of these due process standards were merely restatements of sixth amendment guarantees, or reasonably related to such guarantees. Others which he noted-for example, the view that due process is violated by vague or indefinite statutes-seem compatible with Black's "law of the land" concept of due process. Professor Haigh also cited such cases as In re Murchison, 349 U.S. 133 (1955), and In re Oliver, 333 U.S. 257 (1948), in which Black referred to the due process provisions as requiring "a fair trial in a fair tribunal." It is likely, however, that Black meant by this phrase simply a trial in conformity with the "law of the land"-one includimg specific constitutioual guarantees.

92. Boddie v. Connecticut, 401 U.S. 371, 391 (1971) (Black, J., dissenting). In Boddie, the Court, speaking through Justice Harlan, held that,

given the basic position of the marriage relationship in this society's hierarchy of values and the concomitant state monopolization of the means for legally dissolving this relationship, dne process [prohibits] a State from denying, solely because of inability to pay, access to its courts to individuals who seek judicial dissolution of their marriages. Id. at 374 .

93. In addition to criticisms raised in judicial opinions, commentators liave also been critical. See, e.g., Fairnan, Does the Fourteenth Amendment In- 
tory to justify a "law of the land" interpretation of the due process guarantee. ${ }^{\text {a4 }}$ Moreover, certain critics have pointed to difficulties which they believe to be inherent in attempting to reconcile aspects of Black's total incorporation approach with the words of the fourteenth amendment, ${ }^{95}$ and others have charged that "specific" constitutional provisions are as susceptible to "personal" interpretation as the more general language of the due process clauses. ${ }^{90}$ Whatever their defects, however, it is certainly arguable that Black's total incorporation theory and what has been termed his "fixed concept" of due process ${ }^{27}$ reduce substantially the scope of judicial discretion and provide clearer, more precise legal standards than those implicit in other fourteenth amendment theories. Thus, his approach in these areas reflects two basic tenets of his positivist judicial philosophy.

What of Justice Douglas' views regarding the nature of due process and the relationship between the Bill of Rights and the fourteenth amendment? It would appear from an examination of Betts, Adamson, and Duncan that Douglas' ideas parallel those of Justice Black, for he joined Black's opinions in each of these cases. Furthermore, during his first years on the Court, he seens to have been as enthusiastic a critic as Black of the expansive notions of due process advanced by the economic conservatives on the pre-1937

corporate the Bill of Rights?, 2 STaN. L. Rev. 5 (1949); Mendelson, Mr. Justice Black's Fourteenth Amendment, 53 MINN. L. Rev. 711 (1969). For a listing of the scholars accepting the total incorporation view, see Haigh, supra note 40 , at 33.

94. See, e.g., In re Winship, 397 U.S. 358, $372-73$ n.5 (1970) (Harlan, J., concurring).

95. See, e.g., Mendelson, supra note 93 , at 715.

96. See, e.g., Griswold v. Connecticut, 381 U.S. 479, 501 (1965) (Harlan, J., concurring). Justice Black concluded his Adamson dissent by responding to this charge as follows:

Since Marbury $y$. Madison . . . was decided, the practice has been firmly established, for better or worse, that courts can strike down legislative enactments which violate the Constitution. This process, of conrse, involves interpretation, and since words can have many meanings, interpretation obviously may result in contraction or extension of the original purpose of a constitutional provision, thereby affecting policy. But to pass upon the constitutionality of statutes by looking to the particular standards enumerated in the Bill of Rights and other parts of the Constitution is one thing; to invalidate statutes because of application of "natuural law" [theories of due process] deemed to be above and undefined by the Constitution is another. 332 U.S. at 90-91.

See also H. BLACK, supra note 13, at 35-36.

97. Haigh, supra note 40 , at 24 . Professor Haigh borrowed the terminology from Kadish, Methodology and Criteria in Due Process Adjudication-A Survey and Criticism, 66 YALE L.J. 319, 323 (1957). Professor Kadish contrasted "fixed" and "flexible" approaches to due process interpretation. 
Court. ${ }^{98}$ A close analysis of Douglas' opinions and off-the-bench statements reveals, however, that while he obviously accepts Black's contention that the fourteenth amendment incorporates the Bill of Rights, his concept of due process differs from Black's interpretation in several important respects.

First, whereas Justice Black ascribed to due process a relatively fixed meaning, Douglas views the guarantee as an "evolving" concept. His dissenting opinion in McGautha v. California ${ }^{99}$ perhaps best illustrates this facet of Douglas' due process philosophy. ${ }^{100}$ In McGautha and a companion case, Crampton v. Ohio, ${ }^{191}$ the Court refused to accept the claim that due process is violated when a state fails to provide standards for juries to follow in determining whether to impose the death penalty in capital cases. In Crampton, the Court rejected the further contention that due process is violated in death penalty cases where the jury which determined guilt is also allowed to set the sentence. ${ }^{102}$ In his dissenting opin-

98. See, e.g., Olsen v. Nebraska ex rel. Western Reference \& Bond Ass'n, 313 U.S. 236 (1941). It should be further noted for illustrative purposes that in FPC v. Natural Gas Pipeline Co., 315 U.S. 575 (1942), Justice Douglas joined Justice Black in a concurring opinion which included a caustic attack on the pre1937 Court's concept of due process. The opinion contained the following statement:

Under those views, .... "due process" means no less than "reasonableness judicially determined." In accordance with this elastic meaning which, in the words of Mr. Justice Holmes, makes the sky the limit of judicial power to declare legislative acts unconstitutional, the conclusions of judges, substituted for those of legislatures, become a broad and varying standard of constitutionality. Id. at 600 .

A footnote to the opinion, portions of which were to be quoted frequently by Justice Black in later opinions, read as follows:

To hold that the Fourteenth Amendment was intended to and did provide protection from state invasions of the right of free speech and other clearly defined protections contained in the Bill of Rights .... is quite different from holding that "due process" ... confers a broad judicial power to invalidate all legislation which seems "unreasonable" to courts. In the one instance, courts proceeding within clearly marked constitutional boundaries seek to execute policies written into the Constitution; in the other, they roam at will in the limitless area of their own beliefs as to reasonableness and actually select policies, a responsibility which the Constitution entrusts to the legislative representatives of the people. $l d$. at 600-01 n.4.

99. 402 U.S. 183,226 (1971).

100. See also Poe v. Ullman, 367 U.S. 497, 518 n.9 (1961) (Douglas, J., dissenting), in which Justice Douglas quotes approvingly Justice Owen Roberts' observation:

It is further said that the [due process] concept is a living one, that it guarantees basic rights, not because they have become petrified as of any one time, but because due process follows the advancmg standards of a free society as to what is deemed reasonable and right. Id., quoting 0 .

ROBERTS, THE COURT AND THE CONSTITUTION 80 (1951).

101. 402 U.S. 183 (1971).

102. Justice Black voted with the majority in the cases but wrote a brief concurring opinion emphasizing his opposition to the Court's conclusion that its task 
ion, Justice Douglas criticized what he called the "wooden [due process] position" adhered to in the Court's opinion in the cases. The Court's approach, he charged, could not

be reconciled with the evolving gloss of civilized standards which this Court, long before the time of those who now sit here, has been reading into the protective procedural due process safeguards of the Bill of Rights. It is as though a dam had suddenly been placed across the stream of the law on procedural due process, a stream which has grown larger with the passing years. ${ }^{103}$

Douglas acknowledged that due process had its roots in the Magna Carta; he emphasized, however, that, in the early case of Hurtado v. California, ${ }^{104}$ the Court had recognized that "Magna Carta . . . contained words that changed with ineaning as the centuries passed." 105

Second, as would be expected of a jurist supporting a flexible approach to due process, Douglas, unlike Black, believes that the concept includes standards of procedural "fairness" other than those grounded in the more specific language of the Bill of Rights. In his Crampton dissent, for example, he observed: "The whole evolution of procedural due process has been in the direction of insisting on fair procedures." ${ }^{106}$ Elsewhere in the opinion, after citing the specific procedural guarantees of the Bill of Rights, he stated: "Other requireinents of procedural due process are only implied, not expressed; their inclusion or exclusion turns on the basic question of fairness." ${ }^{" 107}$ In 1970, inoreover, Douglas joined the majority holding in the Winship case that proof of guilt beyond a reasonable doubt was essential to "fair treatment."108

Finally, although he considers due process to be primarily a procedural concept, ${ }^{109}$ Douglas has taken the position that "[d]ue process in the Umited States continues to have a substantive, as well as a procedural significance," committing the judicary "to protect the citizen agaimst arbitrary and capricious acts of both the federal and the state legislatures."110 Indeed, in one of his writings, Douglas

was to determine whether the petitioners' trials were "fairly conducted." 402 U.S. at 225 .

103. 402 U.S. at 241.

104. 110 U.S. 516,529 (1884).

105. 402 U.S. at 243 .

106. Id. at 242 .

107. $1 d$. at 235 .

108. 397 U.S. at 359.

109. In Boddie v. Connecticut, 401 U.S. 371, 384 (1971), Justice Douglas, in a concurring opinion, wrote: "Whatever residual element of substantive law the Due Process Clause may still have, . . . it essentially regulates procedure."

110. W. Douglas, We THe Judges 282 (1956). 
tempered a discussion of the latitude given legislative bodies under the post-1937 Court's due process approach with the following observation:

This does not mean that legislators have carte blanche, that the States can enact any laws they choose, that there are no limits to regulation. While the Court these days does not strike down laws because it deems them unwise, improvident, or mexpedient, it stands ready to act once the outside limits have been breached. What those limits are is impossible to define, except in terms of the concrete. ${ }^{111}$

This aspect of Justice Douglas' due process thinking is clearly and fundamentally at odds with Black's "law of the land" interpretation: it is doubtful whether, apart from prohibiting vague and ex post facto laws, due process, as construed by Black, placed any independent substantive limitations on governmental power.

Justice Douglas' dissenting opinion in Poe v. Ullman ${ }^{112}$ contaims perhaps the most fully developed exposition of his substantive due process views. In Poe, the Court avoided once again ${ }^{113}$ a ruling on the constitutionality of the 1879 Connecticut law prohibiting the use of contraceptives, eventually declared invalid in Griswold $v$. Connecticut. ${ }^{114}$ Douglas claimed in his dissent ${ }^{115}$ that the law infringed unduly upon a right of privacy guaranteed by the fourteenth amendment due process clause. ${ }^{116}$ His line of reasoning may be briefly summarized as follows.

1. The fourteenth amendment's due process clause includes within its meaning the first eight amendments, but is not restricted and confimed to them. ${ }^{117}$ The "liberty" guaranteed by the Constitution's due process provisions "is a conception that [also] sometimes gaims content froin the emanations of other specific guarantees .... or from experience with the requirements of a free society. $" 118$

111. Id. at 281.

112. 367 U.S. 497 (1961).

113. See Tileston v. Ullman, 318 U.S. 44 (1943).

114. 381 U.S. 479 (1965).

115. Justice Black also dissented on the basis of his belief "that the constitutional questions should be reached and decided." 367 U.S. at 509. However, he filed no opinion in the case.

116. See 367 U.S. at 515. Justice Douglas, it should be noted, had also raised, in his dissent in the earher case of Pubhic Util. Comm'n v. Pollak, 343 U.S. 451 (1952), the contention that the Constitution's due process provisions include a right to privacy.

117. 367 U.S. at 516. In the Adamson case, of course, Douglas had declined to join the dissenting opinion of Justice Murphy, which subscribed to this "incorporation-plus" position. Adamson v. California, 332 U.S. 46, 124 (1947) (Murphy, J., dissenting).

118. 367 U.S. at 517. 
2. The "old Court" did not err "in entertaining inquiries concerning the constitutionality of social legislation" under due process standards; rather, it erred "in applying the standards that it did."110 A "free society needs room for vast experimentation," and the pre1937 Court simply failed to recognize that fact. Nevertheless,

to say that a legislature may do anything not within a specific guarantee of the Constitution may be as crippling to a free society as to allow it to override specific guarantees so long as what it does fails to shock the sensibilities of a majority of the Court. ${ }^{120}$

In rejecting the due process approach of the economic conservatives on the Old Court, there are those who would "go so far as to suggest that whatever the majority in the legislature says goes . . . that there is no other standard of constitutionality"121 than that contained in specific constitutional provisions. Such an approach, however,

reduces the legislative power to sheer voting strength and the judicial function to a matter of statistics. As Robert M. Hutchins has said, "It is obviously impossible to raise questions of freedom and justice if the sole duty of the court is to decide whether the case at bar falls within the scope of the duly issued command of a duly constituted sovereign. ${ }^{122}$

3. One form of "liberty" guaranteed by the due process clause is the right to privacy, a right "that is implicit in a free society" and "emanates from the totality of the constitutional scheme under which we live." 123 The Cormecticut contraceptive statute interferes unconstitutionally with this right of privacy and thus violates due process.

Assuming this description of Justice Douglas' interpretation of due process to be an accurate one, it appears that he conceives of due process as establishing far broader and more flexible limitations on governinental power than those inherent in Justice Black's "law of the land" definition of the concept. ${ }^{124}$ It seems equally clear

119. $7 d$.

120. Id. at 518.

121. $1 d$.

122. Id., quoting R. Hutchins, Two FACES OF Federalism 18 (1960).

123. 367 U.S. at 521.

-124. Perhaps because Justices Black and Douglas were so frequently allied in voting on the Court, each tended to avoid direct attacks on the other's views when they reached opposite conclusions in a case. This was certainly true in the due process field, but Sniadach v. Family Fin. Corp., 395 U.S. 337 (1969), was an exception. In Sniadach, Douglas, speaking for the majority, held violative of due process a Wisconsin garnishment procedure under which a debtor's wages could be summarily attached by a creditor without notice or hearing, pending a trial of the issues which had prompted the garnishment action. Justice Black filed a vigorous dissenting opinion in the case, maintaining that, in his judgment, 
that, just as Black's notions regarding due process were coinpatible with his judicial philosophy, Justice Douglas endorses a view of due process substantially in harmony with the highly creative role for judges imphicit in his conception of the judicial function.

\section{The “Penumbral” Concept}

In 1965, Justice Douglas' position that Connecticut's contraceptive law was unconstitutional finally prevailed. Speaking for the Court in Griswold v. Connecticut, ${ }^{125}$ Douglas characterized the law as a sweeping invasion of "a right of privacy older than the Bill of Rights."126 On this occasion, however, Douglas-possibly in an unsuccessful effort to persuade Black to join the Court's decisiondeclined the "invitation" to accept arguments "that implicate the Due Process Clause of the Fourteenth Amendment"127 and instead sought to tie the right of privacy to the specific language of the Bill of Rights through application of a "penumbral" doctrine. ${ }^{128}$ Since Douglas' concept of constitutional penumbras is a further reflection of his judicial approach, and since Justice Black, faithful to his own judicial philosphy, rejected the penumbral notion as employed by Douglas, brief attention should be focused on this aspect of their opposing views on constitutional issues.

In his majority opinion in Griswold, Douglas pointed to earlier cases ${ }^{129}$ which, as he read them, "suggest[ed] that specific guarantees in the Bill of Rights have penumbras, formed by emanations

the Court's decision was based on the policy views of those in the majority. Id. at 344 . In an addendum to his dissent, he criticized once again "natural law" theories of due process, observing:

All of these so-called tests represent nothing more or less than an implicit adoption of a Natural Law concept which under our system leaves to judges alone the power to decide what the Natural Law means. Thcse so-called standards do not bind judges within any boundaries that can be precisely marked or defined by words for holding laws unconstitutional. On the contrary, these tests leave them wholly free to decide what they are convinced is right and fair. If the judges, in deciding whether laws are constitutional, are to be left only to the admonitions of their own consciences, why was it that the Founders gave us a written Constitution at all? Id. at $350-51$.

125. 381 U.S. 479 (1965).

126. Id. at 486 .

127. Id. at 481-82.

128. Id. at 484. Actually, Justice Douglas had alluded to such an approach to the privacy issues raised by the Counecticut law in his Poe dissent, where he observed: "'Liberty' is a conception that sometimes gains content from the emanations of other specific guarantees ...." Poe v. Ullman, 367 U.S. 497, 517 (1961).

129. E.g., NAACP v. Alabama ex rel. Patterson, 357 U.S. 449 (1958); Martin v. City of Struthers, 319 U.S. 141 (1943); Pierce v. Society of Sisters, 268 U.S. 510 (1925); Meyer v. Nebraska, 262 U.S. 390 (1923). 
from those guarantees that help give them life and substance."130 "Without those peripheral rights," he maintained, "the specific rights would be less secure."131 One such "peripheral" or "penumbral" right, he concluded, is the right of privacy, which einanates from several Bill of Rights guarantees imcluding the first, third, and fourth ainendinents, the fifth amendment protection against coinpulsory self-incrimination, and the ninth amendinent admonition: "The enumeration in the Constitution, of certain rights, shall not be construed to deny or disparage othcrs retained by the people."132

More recently, Justice Douglas utilized the penumbral idea in Palmer $v$. Thompson, ${ }^{133}$ the case involving the closing of a niunicipal swimming pool in Jackson, Mississippi. After a district court decision holding that enforced segregation in the city's recreational facilities constituted a denial of equal protection of the laws, ${ }^{134}$ Jackson had desegregated its public parks, auditoriums, golf course, and zoo. However, the city council decided to close its public swimming pools rather than operate them on a desegregated basis. When a challenge to this decision was rejected in the lower federal courts, the case was appealed to the Supreme Court. Speaking for the majority, Justice Black rejected thirteenth and fourteenth amendment claims that the city's action was unconstitutional. "[N]either the Fourteenth Amendinent nor any Act of Congress," he noted, "purports to impose an affirmative duty on a State to begin to operate or to continue to operate swimming pools."135 In addition, there was no evidence "to show the city is directly or indirectly involved in the funding or operation" of private swimming pools, ${ }^{136}$ or that the decision to close "the public pools authorizes or encourages private pool owners to discriminate on account of race."

130. 381 U.S. at 484 . It is readily arguable, however, that the cases cited are of extremely doubtful value as evidence of the Court's past support of the penumbral doctrine, at least as articulated and apphed in the Griswold case.

131. Id. at $482-83$.

132. Id. at 484.

133. 403 U.S. 217 (1971). See also United States v. Vuitch, 402 U.S. 62 (1971), where the Court, speaking through Justice Black, refused to hold a District of Columbia abortion provision unconstitutionally vague. Justice Douglas dissented in part, declaring the statute to be violative of procedural due process requirements. In his opinion, he observed:

Abortion touches intimate affairs of the family, of marriage, of sex,

which in Griswold v. Connecticut ... we held to involve rights associ-

ated with several express constitutional rights and which are summed up

in "the right of privacy." Id. at 78.

134. Clark v. Thompson, 206 F. Supp. 539 (S.D. Miss. 1962), aff'd, 313 F.2d

637 (5th Cir.), cert. denied, 375 U.S. 951 (1963).

135. 403 U.S. at 220.

136. Id. at 222.

137. Id. at 223. 
sponse to the argument that closing the pools violated equal protection "because the decision ... was motivated by a desire to avoid integration of the races," Black maintained that no precedent existed for holding a law violative of "equal protection solely because of the motivations of the men who voted for it."138 Moreover, he emphasized that, in his view, declaring laws unconstitutional on the basis of a finding of "illicit motivation" was a hazardous process. "First," he wrote, "it is extremely difficult for a court to ascertain the motivation, or collection of different motivations, that lie behind a legislative enactment." ${ }^{\text {139 }} \mathrm{He}$ added:

Furthermore, there is an element of futility in a judical attempt to invalidate a law because of the bad motives of its supporters. If the law is struck down for this reason, rather than because of its facial content or effect, it would presumably be valid as soon as the legislature or relevant governing body repassed it for different reasons. ${ }^{140}$

In the final section of his opinion, Black declared that a decision construing the thirteenth amendment to require continued operation of the pools on a desegregated basis "would severely stretch its short simple words, ... do violence to its history, [and] grant [the Court] a lawmaking power far beyond the imaginations of the ainendinent's authors."141

Justice Douglas' dissenting opinion touched upon a number of possible constitutional grounds on which to rest his conclusion that the case had been wrongly decided. He suggested, for exannple, that the ninth amendinent had "a bearing on the present problem." Noting that "[r]ights, not exphicitly mentioned in the Constitution, have at times been deemed so elementary to our way of life that they have been labeled as basic rights," 142 he observed:

There is, of course, not a word in the Constitution, unlike many modern constitutions, concerning the right of the people to education or to work or to recreation by swimming or otherwise. Those rights ... may well be rights "retained by the people" under the Ninth Amendment. ${ }^{143}$

He concluded, however, that there was no immediate need to resolve questions regarding the meaning of the ninth amendment, for the closing of the pools involved "analogies to rights secured by the Bill of Rights or by the Constitution itself." 144 The city's action,

138. Id. at 224.

139. Id.

140. Id. at 225.

141. Id. at 226-27.

142. Id. at 233.

143. Id. at 233-34.

144. Id. at 238. 
he claimed, violated a right within "the penumbra of the . . . Thirteenth, Fourteenth, and Fifteenth Amendments"-namely, the right to be protected against discontinuance by a state of "any of its municipal services . . . for the purpose of perpetuating or imstalling apartheid or because it finds life in a multi-racial community difficult or unpleasant." ${ }^{145}$ Penumbral rights, he urged, must be included within "the category of those enumerated rights protected by the Ninth Amendment. If not included, those rights become narrow legalistic concepts which turn on the formalism of laws, not on their spirit."146

As Justice Black noted in his Griswold dissent, ${ }^{147}$ he favored a "liberal reading" of constitutional provisions; but, to him, the penumbral concept as employed by Justice Douglas involved more than a "liberal" interpretation of the Constitution. In fact, it was his belief that Douglas' talk in Griswold about penumbras and emanations "finally nierge[d]" with the "natural-law-due-process" theories set forth in the Griswold concurring opinions of Justices Harlan, White and Goldberg, and with the "natural law" philosophies of economic conservatives on the pre-1937 Court. ${ }^{148}$ In answering Douglas' Griswold rationale, Black acknowledged that a number of states had enacted statutes providing tort rehef for persons whose private affairs liad been exploited and that, in others, state courts had provided similar relief through their powers as courts of common law. He emphasized, however, that the Supreme Court is not empowered to sit as a common law court and asserted that, although there were "guarantees in certam specific constitutional provisions which are designed in part to protect privacy at certain times and places with respect to certam activities," the Constitution contained no general safegnard for individual privacy. ${ }^{140} \mathrm{He}$ added:

One of the most effective ways of diluting or expanding a constitutionally guaranteed right is to substitute for the crucial word or words of a constitutional guarantee another word or words, more or less flexible and more or less restricted in meaning. This fact is well illustrated by the use of the term "right of privacy" as a comprehensive substitute for the Fourth Amendment's guarantee against "unreasonable searches and seizures." "Privacy" is a broad, abstract and ambiguous concept which can easily be shrunken in meaning but which can also, on the other hand, easily be interpreted

145. Id. at 239.

146. Id.

147. 381 U.S. at 509.

148. Interview with Hugo L. Black, supra note 13.

149. 381 U.S. at 508. 
as a constitutional ban against many things other than searches and seizures . . . . For these reasons I get nowhere in this case by talk about a constitutional "right of privacy" as an emanation froin one or more constitutional provisions. ${ }^{150}$

Justice Black was not persuaded either that the words of the ninth amendment lend support to the penumbral argument-or, for that matter, to what he deemed "natural-law-due-process" notions. As he construed them, the amendment's provisions meant "practically nothing," through the amending process, to enlarge the scope of individual rights given constitutional protection. Clearly, he believed, the amendment was not intended to broaden the powers of government: "If any broad, unlimited power to hold laws unconstitutional . . . is vested in this Court by the Ninth Amendment, the Fourteenth Amendment, or any other provision of the Constitution, it was not given by the Framers, but rather has been bestowed on the Court by the Court."152

\section{The Scope of THE Fourth AMENDMENT}

The concern of Justice Douglas that individual privacy be accorded broad constitutional protection and the judicial approaches of both Black and Douglas are further reflected im their opposing views regarding the scope of the fourth amendment. Not infrequently, the two jurists were found on opposite sides in cases involving a determination of what constitutes an "unreasonable" search or seizure under the amendment, with Justice Black assuming a stance decidedly more permissive of governmental imvestigatory practices than that adhered to by Justice Douglas. ${ }^{153}$ Moreover, Black was apparently less certain than Douglas that the Constitution required exclusion at trial of evidence seized through an unreasonable search; and they also differed somewhat over the nature of the constitutional foundation on whicls to rest the exclusionary rule. ${ }^{154}$ They were perhaps most deeply divided in the fourth amendment area, however, over the question whether eavesdropping is within the ambit of the phrase "searches and seizures" and

150. Id. at 509-10.

151. Interview with Hugo I. Black, supra note 13.

152. 381 U.S. at 520 .

153. See, e.g., Coolidge v. New Hampshire, 403 U.S. 443 (1971); Whiteley v. Warden, 401 U.S. 560 (1971); Chimel v. California, 395 U.S. 752 (1969); Terry v. Ohio, 391 U.S. 1 (1968).

154. See, e.g., Coolidge v. New Hampshire, 403 U.S. 443 (1971); Mapp v. Ohio, 367 U.S. 643 (1961); Wolf v. Colorado, 338 U.S. 25 (1949). 
thus subject to fourth and fourteenth amendment standards.

In the historic case of Olmstead $v$. United States, ${ }^{155}$ the Supreme Court had refused in 1928 to hold that wiretapping constituted a search or seizure. According to the Olmstead Court's reading of the fourth amendment, there could be no search without a trespass and the amendment's seizure provisions extended only to tangible objects. In 1967, however, the Court, in Berger v. New York ${ }^{150}$ and Katz v. United States, ${ }^{157}$ abandoned the Olmstead rule, observing in Katz that the "underpinnings" of Olmstead had "been so eroded by ... subsequent decisions that the 'trespass' doctrine there enunciated can no longer be regarded as controlling." 158 Under the rule established in Berger and Katz, government eavesdropping must conform to the requirements of the fourth amendment.

Early in their careers on the Court, Black and Douglas jomed the majority in Goldman v. United States, ${ }^{169}$ reaffirming the Olmstead doctrine, but ten years later, Justice Douglas announced that he could no longer subscribe to Olmstead. In a dissenting opimion in On Lee v. United States, ${ }^{160}$ he wrote:

I now more fully appreciate the vice of the practices spawned by Olmstead and Goldman. Reflection on them has brought new insight to me. I now feel that I was wrong in the Goldman case. Mr. Justice Brandeis in his dissent in Olmstead espoused the cause of privacy-the right to be let alone. What he wrote is an historic statement of that point of view. I cannot improve on it. ${ }^{101}$

In post-On Lee cases, including Berger and Katz, Justice Douglas has continued to endorse the position that the fourth amendment protects personal privacy from "unreasonable" invasion through surveillance techniques. ${ }^{102} \mathrm{He}$ has also voiced increasing concern over the proliferating use of sophisticated eavesdrop devices in American society. In Osborn v. United States, ${ }^{163}$ for example, he exclaimed in dissent:

155. 277 U.S. 438 (1928).

156. 388 U.S. 41 (1967).

157. 389 U.S. 347 (1967).

158. Id. at 353.

159. 316 U.S. 129 (1942).

160. 343 U.S. 747 (1952).

161. Id. at 762-63.

162. See, e.g., Osborn v. United States, 385 U.S. 323, 340 (1966) (Douglas, J., dissenting); Silverman v. United States, 365 U.S. 505, 512 (1961) (Douglas, J., concurring). Indeed, Justice Douglas would apparently give Berger and Katz a broader reading than the Burger Court is willing to accept. See, e.g., United States v. White, 401 U.S. 745, 756 (1971).

163. 385 U.S. 323 (1966). 
We are rapidly entering the age of no privacy, where everyone is open to surveillance at all times; where there are no secrets from government. The aggressive breaches of privacy by the Government increase by geounetric proportions . . . .164

Justice Black dissented from the majority holdings in the Berger and Katz cases; in Katz he was the lone dissenter. Black beheved that application of the fourth amendinent to eavesdrop practices simply could not be squared with what he considered to be the "literal" meaning of the amendinent's language. ${ }^{165}$ Eavesdropping, he contended in his Katz dissent, was practiced at the time the fourth amendinent was written, and had its framers wished to bring eavesdropping within the scope of the amendinent's provisions, they would have done so through appropriate language. "They certainly would not have left such a task to the ingenuity of language-stretching judges."166 He concluded:

164. Id. at 341. Elsewhere in the dissent, Douglas continued this theme, emphasizing that protection of privacy is essential to the enjoyment of other constitutional rights.

If a man's privacy can be invaded at will, who can say he is free? If his every word is taken down and evaluated, or if he is afraid every word may be, who can say he enjoys freedom of speech? If his every association is known and recorded, if the conversations with his associates are purloined, who can say he enjoys freedom of association? When such conditions obtain, our citizens will be afraid to utter any but the safest and most orthodox thoughts; afraid to associate with any but the most acceptable people. Freedom as the Constitution envisages it will have vanished. Id. at 354 .

See also, United States v. White, 401 U.S. 745, 756 (1971) (Douglas, J., dissenting); W. Douglas, PoINTS of Rebellion 19, 29-30 (1970).

165. In his Katz dissent, Justice Black set forth his views at some length:

The first clause protects "persons, houses, papers, and effects, against unreasonable searches and seizures ....." These words connote the idea of tangible things with size, form, and weight, things capable of being searched, seized, or both. The second clause of the Amendment still further establishes its Framers' purpose to limit its protection to tangible things by providing that no warrants shall issue but those "particularly describing the place to be searched, and the persons or things to be seized." A conversation overheard by eavesdropping, whether by plain snooping or wiretapping, is not tangible and, under the normally accepted meaning of the words, can neither be searched nor seized. In addition, the language of the second clause indicates that the Amendment refers not only to something tangible so it can be seized but to something already in existence so it can be described. Yet the Court's interpretation would have the Amendment apply to overhearing future conversations which by their very nature are nonexistent until they take place. How can one "describe" a future conversation, and, if one cannot, how can a magistrate issue a warrant to eavesdrop one in the future? It is argued that information showing what is expected to be said is sufficient to limit the boundaries of what later can be adinitted into evidence; but does such general information really meet the specific language of the Amendment which says "particularly describing"? Rather than using language in a completely artificial way, I must conclude that the Fourth Amendment simply does not apply to eavesdropping. 389 U.S. at 365-66.

See also Berger v. New York, 388 U.S. 41, 70 (1967) (Black, J., dissenting). 166. 389 U.S. at 366. 
Since I see no way in which the words of the Fourth Amendment can be construed to apply to eavesdropping, that closes the matter for me. In interpreting the Bill of Rights, I willingly go as far as a liberal construction of the language takes me, but I simply cannot in good conscience give a meaning to words which they have never before been thought to have and which they certainly do not have in common ordinary usage. I will not distort the words of the Amendinent in order to "keep the Constitution up to date" or "to bring it into harmony with the times." It was never meant that this Court have such power, which in effect would make us a continuously functioning constitutional convention. ${ }^{\mathbf{1 6 7}}$

By refusing to go beyond what he saw as the "literal" meaning of the fourth amendment's provisions and eschewing an interpretation believed by Douglas, among others, to be necessary to the continuation of a free society, Justice Black was faithful to the basic tenets of his positivist legal philosophy. Similarly, Justice Douglas' view of the fourth amendment as an additional constitutional tool for protecting the sanctity of individual privacy from governmental invasion seems compatible with the picture of his judicial approach outlined earlier in this article. Although their differences on the question were somewhat inore subtle, their opposing concepts of the judicial role were equally obvious in conflicts over the scope of what has become the most significant constitutional tool for protecting "judicially 'sculpted' values"168_the equal protection clause.

\section{Black and Douglas on EQual Protection}

During Justice Black's last years on the Court, he and Justice Douglas differed to a great extent on a number of questions raised in equal protection cases. Black, for example, had a soinewhat inore limited view than Douglas of the power of Congress to enforce the provisions of the fourteenth and fifteenth ainendinents. ${ }^{100}$ They also differed at times over the degree of governmental involvement in private activities which must be shown before those activities can be held subject to constitutional requirements and over the extent to which a private activity must possess a "pubhe" character before being deeined "state action" within the meaning of the Constitution. ${ }^{170}$ Moreover, Black refused to agree with Douglas and others

167. Id. at 373.

168. Michelman, Forward: On Protecting the Poor Through the Fourteenth Amendment, 83 HaRv. L. REv. 7,17 (1969).

169. See, e.g., Perkins v. Matthews, 400 U.S. 379 (1971); Oregon v. Mitchell, 400 U.S. 112 (1970); Allen v. State Bd. of Elections, 393 U.S. 544 (1969); South Carolina v. Katzenbach, 383 U.S. 301 (1966).

170. See, e.g., Evans v. Abney, 396 U.S. 435 (1970); Bell v. Maryland, 378 U.S. 226 (1964); Griffin v. Maryland, 378 U.S. 130 (1964). For an illustration 
that state courts violate equal protection when they enforce trespass laws against persons excluded from private property on racial grounds, even where the decision to segregate was free of judicially cognizable state influence. ${ }^{171}$ And in at least one instance, they were on opposite sides in a case the outcome of which turned on the question whether the state action at issue had reached the threshold of impermissible influence over private discrimination. ${ }^{\mathbf{1 7 2}}$ The focus in this article, however, will be on contrasts in their views regarding the content of equal protection, for it is this aspect of their differences in the equal protection field which is inost clearly reflective of their conflicting approaches to the judicial function. ${ }^{173}$

One of the important developments of the Warren Court was its expansion of the scope of the fourteenth amendment by the developinent of the "suspect criteria" and "fundamental rights" branches of equal protection doctrine. ${ }^{174}$ This "new" equal protection philos-

of their differeuces in a non-equal protection context, see Food Employees Local 590 v. Logan Valley Plaza, Inc., 391 U.S. 308 (1968).

171. See, e.g., Bell v. Maryland, 378 U.S. 226 (1964). Justice Douglas, it should be uoted, has intimated that he might not be ready to accept "the proposition that a state court cannot enforce any private discrimination if the State could not itself make that discrimination." Douglas, Some Dicta on Discrimination, 3 LoyolA (L.A.) L. Rev. 207, 214 (1970). He has written:

Such a doctrine, pushed to its logical extreme, would mean that a court could not enforce a private will that draws a racial line. It would mean that a court could not uphold an action of trespass against a white who refused to leave the property of a Black, desiring to exclude him on the basis of his race. Id. at 214-15.

172. Reitman v. Mulkey, 387 U.S. 369 (1967). Black and Douglas agreed, of course, that the due process clause of the fifth amendment prohibits the federal government from denying "equal protection." See, e.g., Bolling v. Sharpe, 347 U.S. 497 (1954).

173. While principally concerned with Douglas' equal protection philosophy, Professor Karst has provided an excellent insight into the contrasts in their equal protection notions. See Karst, supra note 14.

174. Prior to the Warren Court era, the Supreme Court nonnally gave the equal protection clause a narrow reading. Except in racial discrimination cases and other limited-issue areas, classifications were declared unconstitutional ouly where the Court was convinced that they bore no rational relationship to the accomplishment of a legitimate governmental purpose. See, e.g., Daniel v. Family Sec. Life Ins. Co., 336 U.S. 220 (1949); Railway Express Agency, Inc. v. New York, 336 U.S. 106 (1949); Goesaert v. Cleary, 335 U.S. 464 (1948); Kotch v. Board of River Port Pilot Comm'rs, 330 U.S. 552 (1947). Furthernore, the Court was extremely deferential to legislative judgments when equal protection claims were raised, even during the pre-1937 period when the conservative majority was urged to accept such attacks on economic legislation. See C. PrrTCheTt, The AMERican CONSTITUTION 682-83 (2d ed. 1968). The classic analysis of the traditional equal protection philosophy is Tussman \& tenBroek, The Equal Protection of the Laws, 37 CALIF. L. Rev. 341 (1949). The Warren Court applied traditional equal protection standards in economic cases, see, e.g., Morey v. Doud, 354 U.S. 457 (1957) (the only case in over thirty years in which the Supreme 
ophy, particularly its "fundamental rights" branch, is a convenient tool for the creative judge bent on enlarging the scope of constitutional rights; indeed, it has been called "a royal road . . . to a naturallaw Constitution."175 Justice Harlan made the point eloquently in his dissenting opinion in Shapiro v. Thompson. ${ }^{178}$ In Shapiro and

Court has invalidated state economic legislation on equal protection grounds); Williamson v. Lee Optical, Inc., 348 U.S. 483 (1955), and in other isolated instances, see, e.g., McDonald v. Board of Election Comm'rs, 394 U.S. 802 (1969), but its decisions so enlarged the scope of the guarantee in certain equal protection fields that a distinction is now made between the "old" equal protection and the "new." See G. Gunther \& N. Dowling, Cases and Materials on ConstituTIONAL LAw 983 (1970). Chapter 14 of this casebook is an excellent summary of doctrinal developments in the equal protection field. For much more extensive treatments of the "new" equal protection, see Karst, supra note 14; Michelman, supra note 168; Developments in the Law-Equal Protection, 82 HaRv. L. Rev. 1065 (1969).

The doctrinal gloss given the equal protection clause by the Warren Court rested on a foundation created in pre-Warren cases. In earlier decisions, see, e.g., Korematsu v. United States, 323 U.S. 214 (1944); Skinner v. Oklahoma ex rel. Williamson, 316 U.S. 535 (1942), the Court had held that classifications based on race and other inherently "suspect criteria" required closer scrutiny than normally einployed in equal protection cases. The Warren Court's additions to the list of classifications traditionally considered "suspect" included those based on wealth, see, e.g., Harper v. Virginia Bd. of Elections, 383 U.S. 663 (1966); Douglas v. California, 372 U.S. 353 (1963); Griffin v. Illinois, 351 U.S. 12 (1956), and those restricting interstate travel, see Shapiro v. Thompson, 394 U.S. 618 (1969). More significantly, the Court firmly endorsed and more clearly articulated the position that classifications which result in depriving persons of "fundamental rights" or "interests"-including those not specified in the Constitution-bear a heavy burden of justification. For an early expression of this philosophy, see Skinner v. Oklahoma ex rel. Williamson, supra. Among those fundamental interests recognized by the Warren Court or earlier equal protection decisions are the right to vote, see, e.g., Kramer v. Union Free School Dist., 395 U.S. 621 (1969); Harper v. Virginia Bd. of Elections, supra, the right to procreate; Skinner v. Oklahoma ex rel. Williamson, supra; the right to marry, Loving v. Virginia, 388 U.S. 1 (1967); the right to interstate travel, Shapiro v. Thompson, supra; the rights flowing from "intimate, familial" relationships, Levy v. Louisiana, 391 U.S. 68 (1968); see Glona v. American Guar. \& Liab. Ins. Co., 391 U.S. 73 (1968); and perhaps the right to an education, Brown v. Board of Educ., 347 U.S. 483 (1954). Classifications infringing on such rights, and those based on "suspect criteria," could stand only if necessary to promote a legitimate and compelling state interest. Occasionally, in cases involving application of the "new" equal protection standards, the Court will use language employed in traditional equal protection cases; it will speak, for example, of "irrational" classifications. As Professor Karst has noted, however, such terms have become

shorthand descriptions of the Court's conclusion that the state's classification is unconstitutional. Irrationality or arbitrariness in the old sense of an utter lack of justification is not required in order for a classification to be struck down. Rather, the label of irrationality is affixed whenever the state fails to justify its discrimination to the satisfaction of a majority of the Court. Karst, supra note 14, at 735 .

175. Karst, supra note 14, at 745-46.

176. 394 U.S. 618,661 (1969). 
companion cases, the Court declared unconstitutional, on equal protection grounds, state and District of Colưmbia regulations denying welfare benefits to persons who had resided in the jurisdiction less than one year. It was the Court's conclusion that the regulations, which created two classes of needy residents, infringed on the "fundaniental" right to interstate travel, and that the governmental interests claimed to be promoted by the regulations "either may not constitutionally be promoted by government or are not compelling governmental interests."177 In his lengthy dissenting opinion, Justice Harlan focused on the open-ended nature of the "new" equal protection's "fundamental rights" branch:

I think this branch of the "compelling interest" doctrine particularly unfortunate .... It is unfortunate because it creates an exception which threatens to swallow the standard equal protection rule. Virtually every state statute affects important rights. This Court has repeatedly held, for example, that the traditional equal protection standard is applicable to statutory classifications affecting such fundamental matters as the right to pursue a particular occupation, the right to receive greater or smaller wages or to work more or less hours, and the right to inherit property. Rights such as these are in principle indistinguishable from those involved here, and to extend the "compelling interest" rule to all cases in which such rights are affected would go far toward making this Court a "superlegislature" .... I know of nothing which entitles this Court to pick out particular human activities, characterize them as "fundamental," and give them added protection under an unusually stringent equal protection test. ${ }^{178}$

Justice Douglas has sought to discount fears such as those expressed by Justice Harlan in his Shapiro dissent. He has written, for example:

In these days, . . . fears are sometines expressed that the Equal Protection Clause . . . will be converted into an implement with which judges can strike down so-called "undesirable" or "unwise" legislation. I think, however, that that will not come to pass. I think judges have a keen realization that here, as in many other areas of the world, inequality and injustice are endemic in society and that the resolution of these problems must be entrusted in the main to the political processes and not to the courts. ${ }^{179}$

177. Id. at 627 .

178. Id. at 661-62. Justice Harlan's dissent in Shapiro is a good summary, as well as an insightful critique, of the "compelling interest" approach in the equal protection field.

179. Douglas, supra note 171 , at 210. 
Moreover, he insists that the equal protection clause grants government broad discretion in the imposition of classifications.

The Equal Protection Clause is not designed to iron out all inequalities. It could not possibly do so even if such an effort were made. The poor cannot be given all the advantages enjoyed by the rich. Equality in this sense was never the purpose of the Equal Protection Clause. Its aim at most was to eliminate rank or invidious discrimination. Government must always classify, draw lines, and make distinctions. It is ouly in the rare case that equal protection is denied. 180

Even so, Douglas has spoken often of the importance of the equal protection concept. ${ }^{181}$ Furthermore, he has not been as generous to the government as certain of his colleagues in the application of traditional equal protection standards; ${ }^{182}$ and lie is undoubtedly the chief architect, if not the most eloquent exponent, of the "new" equal protection's "fundamental rights" branch. Indeed, its genesis can be traced to his opinion in Skinner v. Oklahoma ex rel. Williamson. ${ }^{183}$

In Skinner, the Court declared invalid, on equal protection grounds, an Oklalioma statute which provided for the sterilization of recidivists convicted of felonies involving moral turpitude but exempted those convicted of "offenses arising out of the violation of the prohibitory laws, revenue acts, embezzlement, or political offenses."184 Speaking for a unanimous Court, Justice Douglas emphasized that "large deference" to states' classification power was required. He added, however,

We are dealing here with legislation which involves one of the basic

180. Id.

181. The following observations are illustrative:

Equal protection under the law is the most important single principle that any nation can take as its ideal. Those who practice it have a strength and unity that other nations lack. Those who practice it give to each minority a sense of belonging. A sense of belonging is, perhaps, the most important community attitude a people can have. W. DovorAs, THE ANATOMY OF IIBERTY 51 (1963).

The main pohtical problein throughout history has been to develop viable societies with multi-racial, multi-rehigious, and multi-ideological communities. History shows that various forms and types of prejudices and discriminations have prevented the people of the world from making any great progress in that direction. The greatest experiment in all of history is here in the United States. What we do in this regard will have vast repercussions the world around, much greater than what we do in outer space or in other aspects of our developing technology. Douglas, supra note 171 , at 208.

182. See Martin v. Walton, 368 U.S. 25 (1961); Morey v. Doud, 354 U.S. 457 (1957); Goesaert v. Cleary, 335 U.S. 464 (1948); Kotch v. Board of River Port Pilot Comm'rs, 330 U.S. 522 (1947).

183. 316 U.S. 535 (1942).

184. Id. at 536. 
civil rights of man. Marriage and procreation are fundamental to the very existence and survival of the race. The power to sterilize, if exercised, may have subtle, far-reaching and devastating effects. In evil or reckless hands it can cause races or types which are inimical to the dominant group to wither and disappear. There is no redemption for the individual whom the law touches. Any experiment which the State conducts is to his irreparable injury. He is forever deprived of a basic liberty. We mention these matters not to reexamine the scope of the police power of the States. We advert to them merely in emphasis of our view that strict scrutiny of the classification which a State makes in a sterilization law is essential, lest unwittingly, or otherwise, invidious discriminations are made against groups or types of individuals in violation of the constitutional guaranty of just and equal laws. ${ }^{185}$

With these words, Douglas, as Professor Karst has written, "began to lay a foundation-a doctrinal foundation-for the most significant constitutional development of our time."188

From this foundation, the Warren Court, particularly during the late 1960 's, significantly expanded the scope of governmental classifications subject to the "new" equal protection, and Justice Douglas wrote the Court's opinion in a number of cases invoking the doctrine. In Harper v. Virginia Board of Elections, ${ }^{187}$ Douglas held for the Court that the poll tax violated equal protection when imposed as a condition for voting in state elections. In his opinion, he emphasized that "[1]ines drawn on the basis of wealth or property, like those of race . . . are traditionally disfavored."188 $\mathrm{He}$ also asserted that the poll tax requirement infringed upon the fundamental political right to vote, and observed:

We have long been mindful that where fundamental rights and liberties are asserted under the Equal Protection Clause, classifications which might invade or restrain them must be closely scrutinized and carefully confined. ${ }^{189}$

Moreover, when the Court held, in Levy v. Louisiana, ${ }^{190}$ that the denial to illegitimate children of the right to recover for the wrongful death of their mother on whom they were dependent constituted invidious discrimination forbidden by the equal protection guarantee, Douglas again spoke for the majority. Noting that the "rights asserted here involve the intimate, familial relationship between a

185. Id. at 541 (emphasis added).

186. Karst, supra note 14 , at 735.

187. 383 U.S. 663 (1966).

188. Id. at 668.

189. Id. at 670 .

190. 391 U.S. 68 (1968). 
child and his own mother," he observed that the Court had been extremely sensitive to basic civil rights. ${ }^{101}$ While these opinions included rhetoric generally associated with traditional equal protection standards, their implication was clear: classifications which are based on "snspect criteria" or infringe "basic" rights bear a heavy burden of justification.

Justice Black joined in Skinner and certain of the Warren Court decisions extending the reach of the equal protection requirement; ${ }^{192}$ in fact, his majority opimon in Williams $v$. Rhodes ${ }^{103}$ is a classic application of the "new" equal protection. Williams was the Wallace elector case in which the Court held violative of equal protection Ohio election regulations which made it extremely difficult for new political parties, or old ones with a small membership, to gain access to the ballot. Speaking for the Court in the case, Black observed that the laws at issue placed burdens on the right to vote and freedom of association-rights which "rank among our most precious freedoms."194 And he concluded: "The State has here failed to show any 'compelling interest' which justifies imposing such burdens on the right to vote and to associate."195

Jnstice Black doubted, however, whether the equal protection concept should ever have been given any "semantic" meaning or allowed to "creep out beyond race," though he thought such developments "inevitable." 196 Moreover, he dissented in Harper, Levy, and Shapiro, and when asked about his use of language characteristic of the "new" equal protection in Williams, he rephed: "Sometimes I have to use words to hold my Court."197 His dissenting opinion in the Harper case is perliaps the inost complete statement of his views regarding the content of equal protection, and there he

191. Id. at 71. See also Douglas' majority opinion in the related case of Glona v. American Guar. \& Liab. Ins. Co., 391 U.S. 73 (1968); cf. Lassiter v. Northampton County Bd. of Elections, 360 U.S. 45 (1959), in which Douglas, speaking for a unanimons Court, employed the traditional equal protection test in upholding a North Carolina literacy test.

192. See, e.g., Williams v. Rhodes, 393 U.S. 23 (1968); Reynolds v. Sims, 377 U.S. 533 (1964); Douglas v. California, 372 U.S. 353 (1963); Griffin v. Illinois, 351 U.S. 12 (1956). It should be noted that the "suspect criteria" branch of the "new" equal protection may be said, in a sense, to have originated with Justice Black's majority opinion in Korematsu v. United States, 323 U.S. 214 (1944).

193. 393 U.S. 23 (1968).

194. Id. at 30.

195. Id. at 31. Ironically, Justice Douglas would have declared the laws invalid on first and fourteenth amendment grounds. 393 U.S. 23, 35 (Douglas, J., concurring).

196. Interview with Hugo L. Black, supra note 13.

197. Id. 
endorsed the traditional principle that "under a proper interpretation of the Equal Protection Clause States are to have the broadest kind of leeway in areas where they have a general constitutional competence to act."198 Thus, his position on equal protection seemed clearly less expansive than that assumed by Justice Douglas.

Undoubtedly, the vague language of the fourteenth amendment influenced Justice Black to urge judicial restraimt in cases involving claims based on the equal protection clause. But Justice Douglas, in Oregon v. Mitchell, ${ }^{199}$ quoted approvingly an observation froin Justice Brennan's opinion in the case that the framers of the fourteenth amendment "understood their Amendment to be a broadly worded injunction capable of being interpreted by future generations in accordance with the vision and needs of those generations."200 In Harper, for example, Justice Douglas, mindful of earlier cases upholding poll tax requirements for voting, ${ }^{201}$ exclaimed: "Notions of what constitutes equal treatment for purposes of the Equal Protection Clause do change."202 In contrast, Justice Black opposed those who, influenced by this sort of thinking, would "use the general language of the Equal Protection Clause as though it provided a handy instrument to strike down state laws which the Court feels are based on bad governmental pohicy." ${ }^{203}$ Black characterized the Court's decision in Harper and Douglas' opinion as a return to "the old 'natural-law-due-process formula," " observing:

I have heretofore had many occasions to express my strong belief that there is no constitutional support whatever for this Court to use the Due Process Clause as though it provided a blank check to alter the meanings of the Constitution as written so as to add to it substantive constitutional changes which a majority of the Court at any given time believes are needed to meet present-day problems. Nor is there in my opinion any more constitutional support for this Court to use the Equal Protection Clause . . . to write into the Constitution its notions of what it thinks is good governmental policy. ${ }^{204}$

In their few terms together on the Court after Warren Burger became Chief Justice, differences in the two jurists' approach to

198. 383 U.S. at 674 .

199. 400 U.S. 112 (1970).

200. Id. at $139-40$.

201. Butler v. Thompson, 341 U.S. 937 (1951) (per curium); Breedlove v. Suttles, 302 U.S. 277 (1937). Justice Black joined a unanimous Court in Breedlove, decided only a few weeks after he took his seat on the Court; he also voted with the majority in Butler. Douglas was not a member of the Court when Breedlove was decided, but he dissented in Butler.

202. 383 U.S. at 669.

203. Id. at 673 .

204. Id. at $675-76$. 
equal protection issues continued to be reflected in their voting and opinions. In Labine v. Vincent, ${ }^{205}$ for example, Justice Black held for the Court that "there is nothing in the vague generalities of the Equal Protection and Due Process Clauses" empowering the Court to nullify a Louisiana statute quite similar to the one declared invalid in the Levy case. ${ }^{208}$ Justice Douglas dissented from this conclusion, joining an opinion by Justice Brennan which argued that the law was unconstitutional even if measured by traditional equal protection standards. Boddie $v$. Connecticut ${ }^{207}$ is equally pertinent. It will be remembered that in Boddie, the Court, speaking through Justice Harlan, held that a state violates due process when it denies indigents seeking a divorce access to the courts solely because of their inability to pay court fees and costs. Justice Douglas joined in the decision but filed a concurring opmion im which he mamtamed: "The Due Process Clause on which the Court relies has proven very elastic in the liands of judges. The doctrine . . . that due process authorizes courts to hold laws unconstitutional when they beheve the legislature has acted unwisely has long since been discarded. I would not invite its revival."208 Douglas would have rested the decision on what he considered to be the more "definite" standards of the equal protection clause. "The reach of the Equal Protection Clause," he wrote, "is not definable with mathematical precision. But in spite of doubts by some, as it has been construed, rather definite guidelines have been developed . . . ."209 Justice Black dissented, observing that neither the due process clause nor the equal protection clause

justifies judges in trying to make our Constitution fit the times, or hold laws constitutional or not on the basis of a judge's sense of fairness. The Equal Protection Clause is no more appropriate a ve-

205. 401 U.S. 532 (1971).

206. Id. at 539 .

207. 401 U.S. 371 (1971).

208. Id. at 384 .

209. Id. at 385. In his majority opinion in Griswold v. Connecticut, 381 U.S. 479, 482 (1965), Justice Douglas also, of course, "decline[d] the invitation" to utilize substantive due process as a basis for declaring Connecticut's anticontraceptive statute unconstitutional. Given his acceptance of substantive due process in his Poe dissent and elsewhere, however, it is probable that his positions in Griswold and Boddie were based on tactical considerations rather than on any deep-seated philosophical opposition to the substantive due process concept. After all, Douglas had played an important role in the post-1937 Court's dismantling of substantive due process barriers in the economic field, and his use of substantive due process as a device for enlarging the scope of personal freedoms given constitutional protection would appear highly incousistent with his rejection of due process challenges to economic legislation. 
hicle for the "shock the conscience" test than is the Due Process Clause. ${ }^{210}$

Since, as we have seen, Justice Black joined the Court in a number of cases applying the "new" equal protection, it can hardly be said that he was committed to apphication of the traditional equal protection approach in all areas. It is possible, however, to reconcile his votes in such cases with the traditional equal protection philosophy which he espoused in his Harper dissent. Like Douglas, Black voted with the Court in the school segregation cases and their progeny; ${ }^{211}$ but, given the historic purpose of the fourteenth amendment, this does not appear to be so marked a departure from traditional equal protection principles. Also, Skinner was an extreme case, and the result might well have been the same had the Oklahoma sterilization law been measured purely by traditional

210. 401 U.S. at 394. Black and Douglas differed in other Burger Court cases involving debates over the content of equal protection and related equal protection issues. See Abate v. Mundt, 403 U.S. 182 (1971); Whitcomb v. Chavis, 403 U.S. 124 (1971); Oregon v. Mitchell, 400 U.S. 112 (1970).

In Evans v. Cornman, 398 U.S. 419 (1970), however, they joined in a decision striking down, on equal protection grounds, a Maryland law denying the vote in state elections to persons living on the premises of the National Institute of Health, a federal enclave within the state. Similarly, in City of Phoenix v. Kolodziejski, 399 U.S. 204 (1970), they joined in a decision declaring invalid, again on equal protection grounds, a statute limiting voting in general obligation bond elections to those paying taxes on real property. While Warren was Chief Justice, Black voted with the Conrt in Cipriano v. City of Houma, 395 U.S. 701 (1969), declaring violative of equal protection a statute similar to the one invalidated in Kolodziejski; but he jomed a concurring opinion by Justice Stewart which concluded that the law violated traditional notions of equal protection. Id. at 707 . Presumably, Black's votes in Kolodziejski and Cornman were based on the same reasoning.

In Gordon v. Lance, 403 U.S. 1 (1971), it should be further noted, Black and Douglas jomed the Court in upholding, against equal protection claims, a West Virginia constitutional and statutory requirement which forbade local governments to incnr bonded indebtedness or increase tax rates beyond those established by the state constitution without the approval of sixty percent of the voters in a referendum.

Justice Douglas took no part in the consideration or decision of James v. Valtierra, 402 U.S. 137 (1971), in which the Court, through Justice Black, rejected equal protection claims against a provision of the California constitution requiring referendum approval for the construction of low-rent public housing projects.

211. E.g., Swann v. Charlotte-Mecklenburg Bd. of Educ., 402 U.S. 1 (1971); Alexander v. Holmes County Bd. of Educ., 396 U.S. 19 (1969); Green v. County School Bd., 391 U.S. 430 (1968); Griffin v. County School Bd., 377 U.S. 218 (1964) (Black, J.); Goss v. Board of Educ., 373 U.S. 683 (1963); Watson v. City of Memphis, 373 U.S. 526 (1963); Cooper v. Aaron, 358 U.S. 1 (1958). Black, of course, was not prepared to go as far as Donglas in extending the rationale of the school segregation cases. See, e.g., Palmer v. Thompson, 403 U.S. 217 (1971). 
standards. He joined the Court's reapportionment decisions, ${ }^{212}$ but one as committed as Black to the principle of popular sovereignty might well have viewed malapportioned governmental bodies as lacking any "rational" basis. Moreover, he was not willing to go to the lengths deeined necessary by Douglas, among others on the Court, in insisting upon mathernatical equality in governmental districting, ${ }^{213}$ nor, apparently, was he as willing as Douglas to extend the implications of the "one man, one vote" rulings to other forins of malapportionment, such as racial gerrymandering. ${ }^{214}$ Along with Douglas, he occasionally sided with the Court in other voting cases upholding fourteenth amendment claims, ${ }^{215}$ but, as his Harper dissent attests, there were limits beyond which he would not go in using the equal protection guarantee as a device for eliminating obstacles to voting.216 Finally, he voted with the Court in several cases protecting indigents from inequities in the appellate process ${ }^{217}$ and in the imposition of punishment, ${ }^{218}$ but, as he einphasized in his opimion im one such case, Griffin v. Illinois, ${ }^{210}$ it was his view that both the equal protection and due process ("law of the land") requirements demand equality in the criminal process. Viewing his participation in the development and application of the "new" equal protection in this way, it seems clear that Black, ever fearful of the uses to which creative judges might put "general" constitutional language, was decidedly more restrained in his approach to equal protection claims than Douglas, about whom an admirer has said:

It is a measure of his stature that he has understood the dominant need of his generation's America and that he has provided leader-

212. E.g., Hadley v. Junior College Dist., 397 U.S. 50 (1970); Reynolds v. Sims, 377 U.S. 533 (1964). See also Colegrove v. Green, 328 U.S. 549, 566 (1946) (Black, J., dissenting). Justice Black wrote the majority opinion in Wesberry v. Sanders, 376 U.S. 1 (1964), applying the "one man, one vote" rule to congressional districting. His opinion based the holding, however, on the command of article I, section 2 of the Constitution that nembers of the United States House of Representatives be chosen "by the People of the several States," perhaps because the language of artiele I, section 2 seemed to him to be a more "specific" basis for the ruling than the more general language of the equal protection clause.

213. Abate v. Mundt, 403 U.S. 182 (1971).

214. Whitcomb v. Chavis, 403 U.S. 124 (1971).

215. E.g., City of Phoenix v. Kolodziejski, 399 U.S. 204 (1970); Evans v. Cornman, 398 U.S. 419 (1970); Cipriano v. City of Houma, 395 U.S. 701 (1969); Carrington v. Rash, 380 U.S. 89 (1965).

216. See also, Kramer v. Union Free School Dist., 395 U.S. 621 (1969).

217. E.g., Douglas v. California, 372 U.S. 353 (1963); Griffin v. Illinois, 351 U.S. 12 (1956).

218. Tate v. Short, 401 U.S. 395 (1971); Williams v. Illinois, 399 U.S. 235 (1970).

219. 351 U.S. 12 (1956). 
ship to make the judiciary into an instrument of positive egalitarian social change. 220

\section{CONCLUSTON}

Hopefully, this article has demonstrated that the opposing views of Justices Black and Douglas on a variety of significant civil liberties issues can be traced to fundamental differences in their concepts of the judicial function. ${ }^{221}$ Douglas went on the Court op-

220. Karst, supra note 14, at 718.

221. An examination of the opposing views of Black and Douglas regarding the constitutional status of "speech-plus" and "symbolic speech" was omitted from the paper, largely because it was believed that such an analysis could best be handled in a general treatment of the significant role played by the two jurists in modern debates over the nature and scope of the first amendinent. Their positions in this area should at least be given brief attention, however, for lere, too, are reflected differences in their concepts of the judge's role.

As is well known, Justice Black took the position that "direct" infringements on first amendment freedoms are absolutely forbidden. See, e.g., H. BLACK, supra note 13, at 45; Justice Black and First Amendment "Absolutes": A Public Interview, 37 N.Y.U.L. REv. 549, $552-54$ (1962). He was opposed, however, to any enlargement of the first amendment's meaning beyond what he deemed to be the "literal" terms of its provisions. Thus, he refused to agree that the amendinent immunized "from governmental interference .... other conduct in addition to [the] ... particularized freedoms" it was intended to protect. H. BLACK, supra note 13, at 45. And he rejected the "symbolic speech," "speech-plus," and related doctrines under which such activities as picketing, street marching, sit-ins, and the wearing of political symbols have been brought within the amendinent's ambit. See, e.g., Timker v. Des Moines Indep. Community School Dist., 393 U.S. 503, 517, 519 (1969) (Black, J., dissenting); Brown v. Louisiana, 383 U.S. 131, 166 (1966) (Black, J., dissenting); Cox v. Lonisiana, 379 U.S. 536, $577-78$ (1965) (Black, J., concurring in part and dissenting in part); NLRB v. Fruit Packers Local 760, 377 U.S. 58, 76-80 (1964) (Black, J., concurring). See also Giboney v. Empire Storage \& Ice Co., 336 U.S. 490 (1949) (Black, J.); Milk Wagon Drivers Local 753 v. Meadowmoor Dairies, Inc., 312 U.S. 287, 299 (1941) (Black, J., dissenting). Moreover, Black did not believe that government was under any compulsion to provide a place for those wishing to express views. See, e.g., Adderley v. Florida, 385 U.S. 39 (1966) (Black, J.); Brown v. Louisiana, supra at 151 (Black, J., dissenting). See also H. BLACK, supra note 13, at 58. Nor did he believe that private property could be invaded for such purposes. See, e.g., Food Employees Local 590 v. Lógan Valley Plaza, Inc., 391 U.S. 308, 327-33 (1968) (Black, J., dissenting); Bell v. Maryland, 378 U.S. 226, 345 (1964) (Black, J., dissenting). See also $\mathrm{H}$. BuAck, supra note 13, at 57-58.

Justice Black realized, of course, that governmental regulations of conduct beyond the scope of the first amendment might nevertheless infringe "indirectly" on freedoms guaranteed by the first amendment. He took the position, however, that such regulations were constitutional if enforced with an even hand and if no other means were available to accomplish the purpose of the regulation and the need to control the conduct involved was sufficient to justify an "indirect effect" on free speech. See, e.g., Cox v. Louisiana, supra at 577-79 (Black, J., concurring in part and dissenting in part). See also $\mathrm{H}$. BLACK, supra note 13 , at $59-61$.

Justice Black's views in this area have been subjected to intense criticism, 
posed to judges who would stamp their economic predilections on the Constitution. His later votes and opimions suggest, however, that his opposition to the decisions of the pre-1937 Court in economic cases probably was based more on a belief that such rulings were

see, e.g., McBride, Mr. Justice Black and his Qualified Absolutes, 2 LoYolı (L.A.) L. REv. 37 (1969), but he continued to adhere to them until the end of his career on the Court. Interview with Hugo L. Black, supra note 13.

Justice Douglas has long agreed that the conduct component in picketing and related forms of "speech-plus" makes such activities susceptible to governmental regulation. In a 1942 labor picketing case, for example, he wrote:

Picketing by an organized group is more than free speech, since it involves patrol of a particular locahty and since the very presence of a picket line may induce action of one kind or another, quite irrespective of the nature of the ideas which are being disseminated. Hence those aspects of picketing make it the subject of restrictive regulation. Teamsters Local 802 v. Wohl, 315 U.S. 769, 776-77 (1942) (Douglas, J., concurring). See also, Gregory v. City of Chicago, 394 U.S. 111, 113 (1969) (Black \& Douglas, JJ. concurring); Food Employees Local 590 v. Logan Valley Plaza, Inc., supra at 326 (Douglas, J., concurring). Unlike Black, though, Douglas beheves that "speech-plus" enjoys some degree of direct protection under the first amendment. See, e.g., W. Douglas, supra note 164, at 4. Moreover, he has been much more willing than Black to strike down governmental regulations applied to "speech-plus." See, e.g., Adderley v. Florida, supra at 48 (Douglas, J., dissenting); Brown v. Louisiana, supra; Cox v. Louisiana, supra. And he has been much more fearful than Black apparently was that governmental regulations, ostensibly applied to accoinplish legitinnate governmental objectives, will be used to censor the expression of ideas. See, e.g., Adderley v. Florida, supra at 48, 54-56 (Douglas, J., dissenting). See also W. Douglas, supra note 164, at 4.

The two also differed in cases involving "symbolic speech" issues. Although he favored a liberal interpretation of constitutional provisions, Justice Black refused to accept the view that conduct designed to communicate an idea was within the purview of the first amendment. Douglas, however, accepts the "symbolic speech" concept. In Tinker v. Des Moines Indep. Community School Dist., supra, for example, he joined the Court in holding, over Justice Black's dissent, that, while school authorities may impose reasonable regulations on the conduct of school children, the wearing of black armbands by children wishing to protest United States policies in Vietnam is protected by the first and fourteenth amendments. In Ferrell v. Dallas Indep. School Dist., 393 U.S. 856 (1968), it should be further noted, Douglas dissented when the Court refused to hear a case involving constitutional claims asserted against school regulations regarding hair length. His dissent was couched largely in equal protection terms, but it included the observation:

[T]he ideas of "life, liberty, and the pursuit of happiness," expressed in the Declaration of Independence, later found specific definition in the Constitution itself, including, of course, freedom of expression and a wide zone of privacy. Id.

In this field also, therefore, Justice Douglas has adhered to an expansive, somewhat open-ended construction of the constitutional guarantees involved. Justice Black, on the other hand, was faithful to what he believed to be their "literal" meaning and historical intent. Black's position in this area is a further reflection too, of his opposition to constitutional standards based on ideas of "reasonableness," though it is doubtful whether his own approach would have provided any clearer, more precise standards, especially in the hands of other judges. 
antithetical to society's needs than on a commitment to "strict" constitutional construction. When first appointed, Douglas undoubtedly considered elimination of constitutional obstacles to economic recovery to be the Court's inost pressing social task. With the Old Court's economic precedents disinantled, however, he came to view the Court's primary work as that of converting the Constitution into an instrument for extending meaningful recognition to those freedoms and egalitarian ideals which he deemed implicit in the concept of a free society; and few justices have inatched him in seeking new constitutional bases for enlarging the scope of individual freedoin against government.

Justice Black also began his years of service on the Court as a critic of the Old Court's conservative economic theories. Moreover, of course, he was a strong defender of constitutional liberties and had a profound personal commitment to their protection, freely conceding, for example, that lie might "be shightly influenced" in his absolutist interpretation of first amendinent guarantees "by the fact that" lie did "not think Congress should make any law with respect to these subjects." ${ }^{222}$ But Black was unwilling to enlarge the scope of constitutional liberties beyond what he believed to be their "hiteral" or historically intended meaning, and he was concerned with establishing, wherever possible, clear, precise constitutional standards, thereby reducing opportunities for the exercise of judicial discretion. He embraced a positivist judicial philosophy which rejected the view that judges should be guided in constitutional interpretations by their notions of what is "just" or most "socially desirable."

Justice Black's opposition to flexible constitutional standards was based to a degree on his behef that such standards could be used to dilute the ineaning of constitutional gnarantees. ${ }^{223}$ Indeed, for him the genius of a written constitution rested in part on the fact that "one purpose of a written constitution is to define and therefore more specifically hmit governmental powers" over individual freedom. ${ }^{224}$ Douglas is obviously opposed also to doctrines inore permissive of governmental power than those based on the "plain" meaning of the Constitution. In two recent criminal procedure cases, ${ }^{225}$ for example, lie asserted in dissent that he was extremely concerned

222. Justice Black and First Amendment "Absolutes," supra note 221, at 553. 223. See, e.g., H. BLACK, supra note 13, at 12.

224. Black, The Bill of Rights, 35 N.Y.U.L. Rev. 865, 869 (1960). See also Haigh, Mr. Justice Black and the Written Constitution, 24 ALA. L. Rev. 15 (1971). 225. Apodaca v. Oregon, 406 U.S. 404 (1972); Johnson v. Louisiana, 406 U.S. 356 (1972). 
when we make the Bill of Rights, as applied to the States, a "watered down" version of what that charter guarantees. My chief concern is one often expressed by the late Mr. Justice Black, who was alarmed at the prospect of nine men appointed for life sitting as a super-legislative body to determine whether government has gone too far.228

Thus, Douglas' constitutional philosophy would appear clearly more acceptable to Black than one which viewed constitutional rights as little more than an admonition to government. Even so, for Black, as one writer has observed, the civil liberties guarantees of the Constitution had a "ceiling" as well as a "floor."227 And Justice Douglas' constitutional constellation apparently admits of no "ceiling."

Assuming that this article has presented an accurate picture of their judicial philosophies and views regarding the scope of constitutional liberties, it is not surprising that the lecture delivered by Justice Douglas in 1963, as part of the New York University School of Law's distinguished James Madison Lecture series, had a somewhat different thrust than the well-known first lecture in the series, presented some years earlier by Justice Black. Justice Black lectured, of course, on "The Bill of Rights." 228 Justice Douglas' lecture was entitled: "The Bill of Rights Is Not Enough."228

226. 406 U.S. at 388 . In the two cases, the Court upheld non-unanimous jury verdicts against constitutional claims. It is very likely that, had he participated in the cases, Justice Black would have joined the majority rather than Justice Douglas, on the ground that the Constitution does not "specifically" require unanimons jury verdicts.

227. Karst, supra note 14 , at 726.

228. Black, supra note 224.

229. Douglas, The Bill of Rights Is Not Enough, 38 N.Y.U.L. Rev. 207 (1963). 